
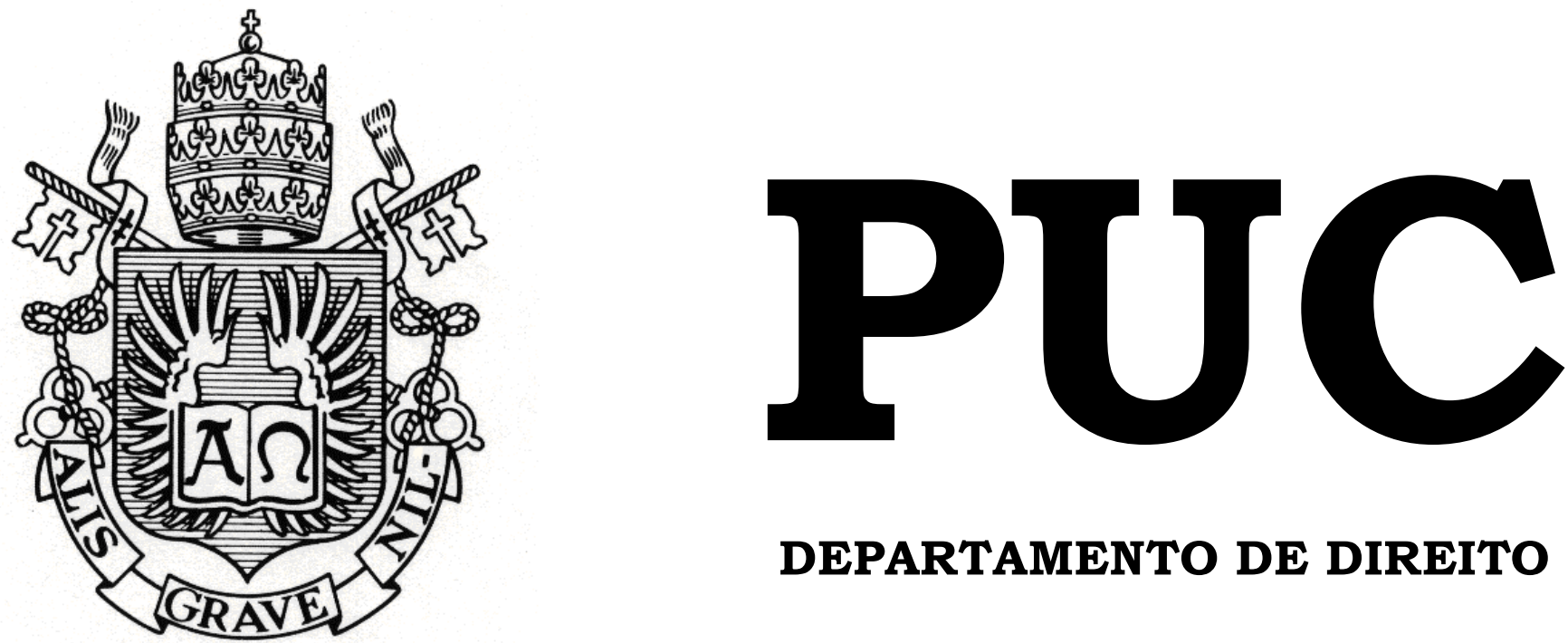

DEPARTAMENTO DE DIREITO

\title{
O COMPROMISSO POLÍTICO-PARTIDÁRIO COM A IGUALDADE DE GÊNERO
}

\author{
por \\ LUCIANA CARPILOVSKY DE VASCONCELLOS
}

ORIENTADORA: ADRIANA VIDAL

2015.1

PONTIFÍCIA UNIVERSIDADE CATÓLICA DO RIO DE JANEIRO

RUA MARQUÊS DE SÃO VICENTE, 225 - CEP 22453-900

RIO DE JANEIRO - BRASIL 


\title{
O COMPROMISSO POLÍTICO- PARTIDÁRIO COM A IGUALDADE DE GÊNERO
}

\author{
por \\ LUCIANA CARPILOVSKY DE VASCONCELLOS
}

Monografia

apresentada

ao

Departamento de Direito da Pontificia Universidade Católica do Rio de Janeiro (PUC-Rio) para a obtenção do Título de Bacharel em Direito.

Orientadora: Adriana Vidal 


\section{DEDICATÓRIA}

À todas as mulheres que têm que fazer o dobro do trabalho dos homens para receberem metade da valorização. À todas as mulheres que, ao escolherem o que queriam ser ou fazer, tiveram que explicar, argumentar, justificar e defender sua decisão. Continuamos a fazê-lo. 


\section{AGRADECIMENTOS}

Este trabalho de conclusão de curso, embora escrito por minhas mãos, não foi realizado somente por mim. Certamente ele é fruto de todos aqueles que me tocam e a quem eu toco e que, portanto, fazem parte de mim. Ao longo desses cinco anos na Faculdade de Direito, aprendi a pensar com minhas próprias ideias (ou com aquelas que acredito que sejam minhas, mas que, no fundo, são reflexos das de outrem) e a enxergar o mundo sob um ponto de vista que jamais imaginaria que poderia chamar de meu. Familiares, amigos e professores guiaram meu caminho e me ajudaram a chegar onde estou, e o espaço que aqui tenho não é suficiente para agradecê-los da maneira apropriada.

Primeiramente, agradeço à minha família. Ao meu pai, que me ensinou a encarar o mundo com um olhar mais crítico, a argumentar e não só pedir por aquilo que eu quero, porque expor suas ideias é mais do que vocalizá-las, e atingir objetivos com seus esforço próprio é muito mais satisfatório. À minha mãe, que sempre acreditou em mim, mesmo quando eu duvidava do que conseguiria fazer, e me ensinou que não se pode dizer que não se sabe fazer alguma coisa sem ao menos tentá-lo primeiro, porque é errando que se aprende e, com toda minha exigência sobre mim mesma, meu medo de errar se conforta em abraços sempre presentes. À minha irmã, que estará sempre ao meu lado, que me protegia quando eu tinha medo do escuro e que aguentou todas as sessões de elaboração de monografia em plena madrugada. Ao meu avô, que me ensinou a acreditar nas pessoas e que permanece sendo meu pilar de força. E especialmente, à minha avó, uma das mulheres mais fortes que conheço, de quem herdei tantos detalhes que fazem parte do meu eu, e para quem eu sei que sempre posso contar o que quiser, na certeza que encontrarei um porto seguro cheio de amor e sabedoria em suas respostas. 
Agradeço aos meus amigos, que estão sempre presentes, mesmo quando distantes, com quem posso dividir as experiências da minha vida e que aguentaram não só meu sumiço da vida real, como também toda minha matemática eleitoral e uma infinidade de curiosidades sobre o funcionamento dos sites da Câmara e do Senado (o que com certeza eles não queriam saber). Em especial, agradeço à Fernanda, à Manuela e à Ana - porque existem certas coisas que não se pode fazer junto sem acabar gostando um do outro, e derrubar um trasgo montanhês de quase quatro metros de altura é uma dessas coisas.

Agradeço, aos meus mestres e professores, em especial, àqueles que me mostraram que Direito é muito mais do que leis e jurisprudência. À Thula Pires, ao Francisco de Guimaraens e à Juliana Bracks.

Agradeço, por fim, à minha orientadora, Adriana Vidal, que me deu a confiança necessária para acreditar nesse trabalho e nas palavras que utilizei para fazê-lo. Obrigada pela dedicação, pela orientação e pelos incentivos que me foram concedidos durante essa jornada. 


\section{RESUMO}

A presente monografia pretende discutir o compromisso políticopartidário com a igualdade de gênero a partir da análise do papel dos partidos políticos nas chances de acesso das mulheres à representação política, particularmente à representação legislativa, em especial, no âmbito do Congresso Nacional. No primeiro momento, os tipos de representação e o sistema partidário são enfocados como dimensões do sistema político e eleitoral, correlacionando os diferentes sistemas com a elegibilidade das mulheres. Em seguida, o sistema partidário é melhor analisado em seus aspectos organizacionais e ideológicos, de modo que é possível refletir sobre alguns condicionantes institucionais intrapartidários que interferem de maneira positiva ou negativa nas chances de as mulheres disputarem pleitos eleitorais e serem eleitas. Posteriormente, discorre-se sobre as diferentes estratégias de adoção de políticas de discriminação positiva. A partir de pesquisa sobre o caso brasileiro, procura-se observar como as características do sistema político e partidário nacional afetam os resultados das cotas, levantando-se críticas e sugestões de soluções apresentadas em uma possível reforma política.

Palavras-Chave: gêneros; representação política; partidos políticos; cotas de gênero; ações afirmativas; ações de discriminação positiva; mulheres e eleições. 


\section{SUMÁRIO}

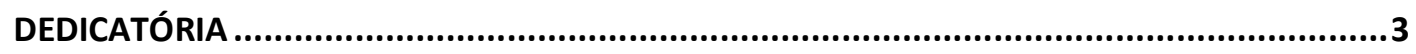

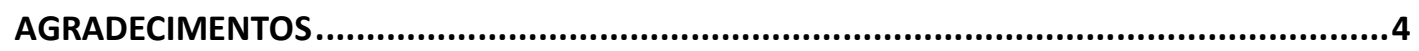

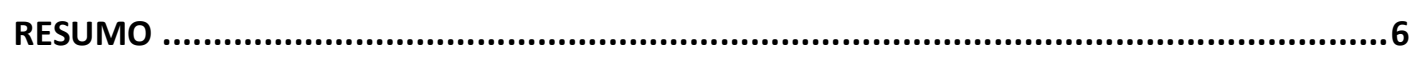

SUMÁRIO

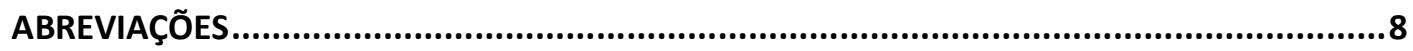

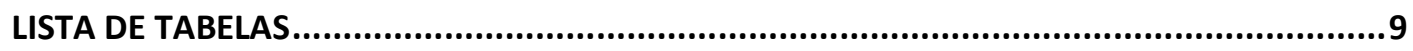

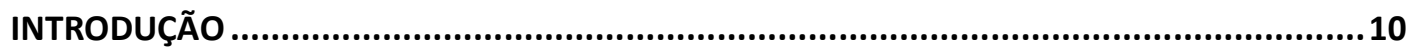

CAPÍTULO I: DEMOCRACIA REPRESENTATIVA - SISTEMA PARTIDÁRIO E REPRESENTAÇÃO POLÍTICA EM UM ESTADO DEMOCRÁTICO DE DIREITO CONTEMPORÂNEO ......................14

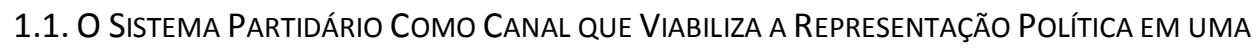

DEMOCRACIA REPRESENTATIVA OCIDENTAL ...................................................... 16

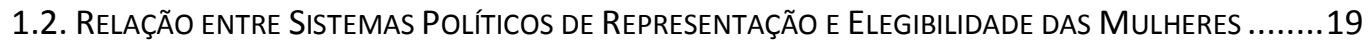

1.3. RELAÇÃo ENTRE Sistemas PARTIdÁRIOS E ElEGIBILIDADE dAS MULHERES .............................24

CAPÍTULO II - CONTEXTOS PARTIDÁRIOS - PERFIS IDEOLÓGICOS E ORGANIZACIONAIS RECRUTAMENTO ELEITORAL E ESTRATÉGIAS DE PROMOÇÃO DE PARIDADE DE GÊNERO .29

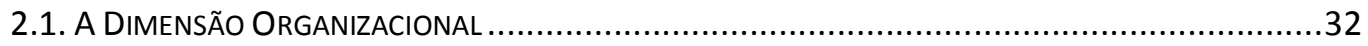

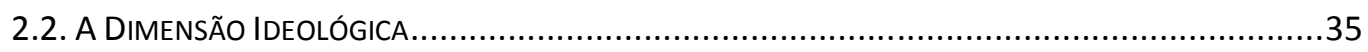

CAPÍTULO III - COTAS ELEITORAIS DE GÊNERO - SUAS MODALIDADES E EXPERIÊNCIAS NO

CAMPO DA REPRESENTAÇÃO POLÍTICA ...........................................................41

3.1. CotAS LEGAIS SOBRE O PROCESSO ElEITORAL ............................................................45

3.2. CotAS LEGAIS DE RESERVA DE ASSENTO PARLAMENTAR ..............................................49

3.3. COTAS PARTIDÁRIAS VOLUNTÁRIAS .............................................................51

CAPÍTULO IV - COTAS ELEITORAIS DE GÊNERO NO BRASIL - ACESSO E INSERÇÃO DA MULHER NO CENÁRIO POLÍTICO BRASILEIRO .........................................................55

4.1. A TRAJETÓRIA DA LEI DE COTAS - AlgunS ANTECEDENTES HISTÓRICOS................................56

4.2. A LegisLaçÃo AtUal E OS Resultados Eleitorais ....................................................60

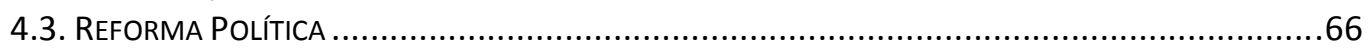

4.3.1. Reforma Política e Igualdade de Gênero ..................................................68

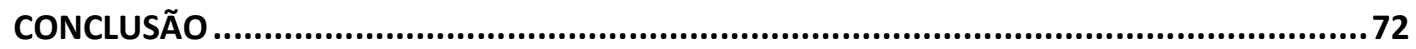

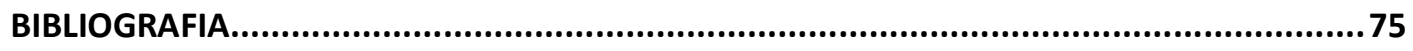

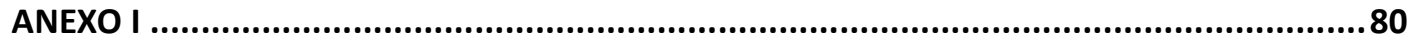




\section{ABREVIAÇÕES}

IPU - Inter-Parliamentary Union / União Interparlamentar

IDEA - International Institute for Democracy and Electoral Assistance /

Instituto Internacional para a Democracia e Assistência Eleitoral

PCdoB - Partido Comunista do Brasil

PMDB - Partido do Movimento Democrático Brasileiro

PMN - Partido da Mobilização Nacional

PP - Partido Progressista

PSB - Partido Socialista Brasileiro

PSD - Partido Social Democrático

PSDB - Partido da Social Democracia Brasileira

PT - Partido dos Trabalhadores

PTC - Partido Trabalhista Cristão

PTN - Partido Trabalhista Nacional

PV - Partido Verde

TSE - Tribunal Superior Eleitoral 


\section{LISTA DE TABELAS}

TABELA 1 - EVOLUÇÃO DAS CANDIDATURAS APTAS AO CARGO DE DEPUTADO FEDERAL POR

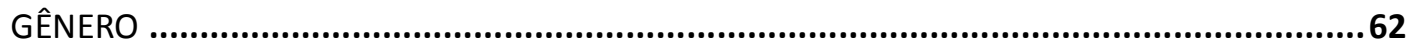

TABELA 2 - CANDIDATURAS INAPTAS AO CARGO DE DEPUTADO FEDERAL POR GÊNERO ELEIÇÕES DE 2014

TABELA 3 - EVOLUÇÃO DO NÚMERO DE ELEITOS PARA O CARGO DE DEPUTADO FEDERAL POR GÊNERO 65

TABELA A - LISTA DE PAÍSES, TIPO DE PARLAMENTO, TIPO DE COTA ADOTADA, SISTEMA

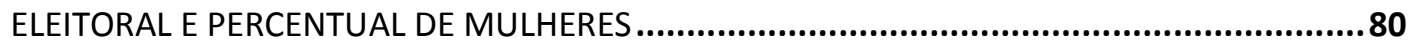




\section{INTRODUÇÃO}

O tema do presente trabalho surgiu no segundo semestre de 2014, com a proximidade das eleições gerais de outubro e com a proliferação de propagandas políticas. Precisamente, o predomínio quase que completo de rostos masculinos nas propagandas para os cargos legislativos, postas em cartazes e cavaletes pelas ruas da cidade e anunciadas nas telas de televisão, possibilitou uma primeira cogitação acerca do tratamento que as candidaturas femininas recebem de seus partidos políticos quando em comparação com seus pares homens. Em face à legislação eleitoral que estabelece, desde 1997, uma cota de gênero para a composição das listas partidárias para os pleitos proporcionais, questiona-se se existe, por parte dos partidos políticos, um compromisso com a igualdade de gênero na política, primeiramente de cunho formal, averiguando-se se o percentual estabelecido pela lei é cumprido, e, posteriormente, por um viés material, verificando-se se os partidos realizam investimentos suficientes em suas candidatas para que estas concorram a cargos eletivos com real potencial de elegibilidade.

Os recorrentes baixos índices de representatividade de mulheres na Câmara dos Deputados, atualmente correspondentes a 10\% de seus assentos, colocam o Brasil no $117^{\circ}$ lugar no ranking de 189 países elaborado pela Inter Parliamentary Union e utilizado como referencia internacional para aferir o acesso das mulheres aos espaços de representação política. $\mathrm{O}$ debate sobre a paridade de gêneros evidencia que a cidadania é construída sobre modelos masculinos, de modo que as mulheres são recorrentemente confrontadas por sua condição de gênero, encontrando diferentes obstáculos ao acesso à elite política, o qual se dá em um cenário de caráter sexuado, caracterizado pela exclusão das mulheres de acordo com aspectos dos sistemas políticos e eleitorais. Nesses termos, questiona-se a legitimidade de uma democracia em 
que a maioria de suas instituições representativas, embora não exclua as mulheres legalmente, o faz factualmente.

O presente trabalho orienta-se por uma análise multivariada dos fatores que constituem aspectos de mediação nas rotas de ingresso político de mulheres e que ajudam a definir padrões de gênero que conformam o acesso à representação política, visando demonstrar as conexões entre o sistema eleitoral e o sistema partidário, como as instituições mais importantes para o desempenho da participação via representação política e a elegibilidade de mulheres. Analisa-se também a disseminação de estratégias adotadas para romper o quadro de sub-representatividade política do gênero feminino, especialmente as experiências de cotas para a competição eleitoral legislativa, e a viabilidade de suas aplicações, considerando-se o lugar ocupado pelos partidos políticos como veículos tradicionais de acesso aos cargos eletivos.

Para atingir o objetivo proposto, são utilizados dados disponíveis no Banco de Dados de Cotas para Mulheres, para realização de comparações com experiências internacionais, e informações disponíveis no Tribunal Superior Eleitoral (TSE), para maior detalhamento sobre a situação brasileira. Compreendendo-se que a política, como ação eleitoral, necessariamente está relacionada com ambientes externos e históricos à volta desse momento específico, busca-se entender sob quais condições políticas e sociais as mulheres tendem a obter melhores ou piores performances eleitorais, investigando-se os motivos que colaboram para a manutenção dos baixos índices de representação, sobretudo, no cenário brasileiro.

A presente monografia tem sua estrutura divida em quatro partes. A primeira será dedicada à caracterização da relevância dos partidos políticos como instrumentos para a viabilização de uma democracia representativa paritária. Se o tema começou a ser pensado a partir do compromisso dos partidos políticos com a igualdade de gênero, faz-se necessário, portanto, apontar a importância do papel que os mesmos desempenham como vetores de 
canalização de vontade política e mediadores das rotas de acesso aos órgãos de representação. No primeiro capítulo, também será abordada a relação entre sistema partidário e sistema eleitoral, entendendo-se que a organização e as práticas partidárias somente podem ser compreendidas considerando-se as variáveis institucionais dos diferentes tipos de sistema eleitoral.

O capítulo seguinte aprofunda a análise sobre o sistema e o contexto partidários, examinando as dimensões internas dos partidos políticos que afetam o processo de recrutamento eleitoral e as chances de grupos minoritários, incluindo-se nestes as mulheres, de alcançarem cargos de significância política. Busca-se apontar fatores de ordem organizacional e ideológica que influenciam o modo como os partidos lidam concretamente com a questão da representação paritária. No segundo capítulo são indicadas diferentes estratégias adotas pelos partidos para absorver as demandas por igualdade de gênero na política.

O terceiro capítulo apresenta, a partir da experiência internacional, os diferentes tipos de cotas eleitorais de gênero existentes. Discorre-se sobre os aspectos internos a uma política de cotas que necessitam ser detalhados para garantir um grau mínimo de efetividade à ação de discriminação positiva. $O$ Capítulo III também busca demonstrar que o sucesso ou insucesso das cotas depende também, em parte, de características dos sistemas eleitorais e partidários em que as mesmas se inserem.

O último capítulo, orientado pelo anterior, aborda o modo como as cotas eleitorais de gênero foram incorporadas no ordenamento brasileiro, apontando os resultados que as mesmas vêm apresentando desde sua implementação, destacando-se a postura assumida pelos partidos políticos face às imposições legais, especialmente, no que tange a garantir o posicionamento de suas candidatas em condições de elegibilidade no pleito eleitoral. Pretendese demonstrar o porquê da ineficácia das cotas brasileiras como estratégia de acesso feminino à representação política, a partir da análise da evolução 
legislativa da Lei de Cotas e sua relação com aspectos do sistema políticoeleitoral nacional. Por fim, o quarto capítulo, introduz o tema de Reforma Política, abordando as questões em debate atualmente no Congresso Nacional, cuja aprovação e adoção podem afetar a proporcionalidade da representatividade parlamentar e as cotas de gênero. 


\section{CAPÍTULO I: DEMOCRACIA REPRESENTATIVA - SISTEMA PARTIDÁRIO E REPRESENTAÇÃO POLÍTICA EM UM ESTADO DEMOCRÁTICO DE DIREITO CONTEMPORÂNEO}

Um regime democrático pode ser qualificado conforme a forma pela qual o povo participa do poder e exerce sua ação política, podendo caracterizar-se como uma democracia direta/participativa, indireta/representativa ou mista. A Constituição da República Federativa do Brasil de 1988 estabelece, em seu artigo $1^{\circ}$ e parágrafo único, que a República Brasileira se constitui em um Estado Democrático de Direito em que "todo poder emana do povo, que o exerce por meios de representantes eleitos ou diretamente". Nesse sentido, os constituintes optaram por um modelo de democracia representativa, temperada com princípios e institutos de uma democracia participativa, garantindo a possibilidade de participação direta dos cidadãos no processo decisório governamental e no processo político ${ }^{1}$.

Abraham Lincoln, em seu discurso em Gettysburg, em 1863, afirmou que democracia é o governo do povo, pelo povo e para o povo, sendo, portanto, um regime que requer a participação ampla da população e de suas organizações de base no processo político e na ação governamental. O conceito de participação política é, em geral, definido a partir de um conjunto de ações dos cidadãos no exercício das reivindicações de seus direitos e no desempenho de suas responsabilidades cívicas, legitimando e fortalecendo as instituições democráticas.

Os estudos sobre a participação política, geralmente, utilizam como parâmetros as formas institucionalizadas de participação, tais como, por exemplo, o exercício do direito de voto, os mandatos parlamentares e executivos e a estruturação de partidos políticos e de organizações

\footnotetext{
${ }^{1}$ SILVA. José Afonso da. Curso de Direito Constitucional Positivo. São Paulo: Malheiros Editores, 2011. p. 145
} 
profissionais. ${ }^{2}$ Todavia, a participação política também pode ser exercida fora do campo convencional e institucional, por meio de atividades políticas autoorientadas, não-estruturadas e, em geral, de caráter urbano, compreendendo ações de grupos organizados sem necessariamente pertencerem a uma rede de relações políticas estaduais ou nacionais. ${ }^{3}$ Nesse sentido, os movimentos sociais urbanos, os protestos políticos e a existência de diversas associações civis de todo o tipo, apresentam-se como um meio de exercício nãoinstitucionalizado de uma ação política.

A representação da diversidade social na política tem se tornado um aspecto cada vez mais relevante para a concretização de uma democracia representativa. Abordando-se a questão sob a perspectiva de gênero, a distribuição da participação dos mesmos no corpo legislativo de uma nação tem sido utilizada como referência internacional para aferir o acesso das mulheres aos espaços de representação política. Nesse sentido, a presença de baixos índices de participação institucionalizada da mulher na arena política diz muito sobre os limites indiretos à participação democrática ${ }^{4}$. Nas palavras de Clara Araújo:

"Isto não implica abraçar a tese de que mais mulheres mudam o parlamento pelo fato de serem mulheres ou que há qualidades diferenciadas por sexo que melhoram ou pioram a democracia ou, ainda, que mulheres irão defender os interesses das mulheres e estes têm o mesmo significado ou sentido para todas as que forem eleitas. Com a ampliação de seu ingresso, há indícios de que sua presença contribui para alargar a agenda política. Mas, acima de tudo, há a questão democrática relevante de sua presença como parcela

\footnotetext{
2 TABAK, Fanny. A necessidade de uma re-conceitualização. In: TABAK, Fanny. Mulheres Públicas: Participação Política e Poder. Rio de Janeiro: Letra Capital, 2002.

3 AVELAR, Lúcia. O Segundo Eleitorado: Tendências do Voto Feminino no Brasil. Campinas: Editora da Unicamp, 1989. P. 87-88

4 ARAÚJO, Clara. Por Que Uma Reforma Eleitoral Mais Ampla É Importante Para As Mulheres? Revista Gênero na Amazônia, no 4, jul./dez., 2013. pp. 37-49.
} 
substantiva ainda outsider dos espaços decisórios. " (ARAÚJO, 2013, p. 38)

Diversos fatores de ordem cultural, socioeconômicos, políticos e contextuais influenciam e estão associados às chances de mulheres se elegerem. Nas últimas duas décadas, estudos comparados internacionais baseados em análises das "famílias" dos sistemas eleitorais evidenciaram que os Sistemas Políticos e Eleitorais interferem e têm bastante influência no acesso de mulheres a cargos políticos eletivos, ajudando a compreender o déficit de gênero nas instituições de poder ${ }^{5}$. Este capítulo tem como objetivo caracterizar a relevância adquirida pelos partidos políticos como instrumento para a viabilização de uma democracia representativa, sua articulação com os sistemas político e partidário, identificando-se tendências associadas aos diferentes sistemas que os tornam mais ou menos "amigáveis às mulheres" na esfera de representação política.

\subsection{O Sistema Partidário Como Canal que Viabiliza a Representação Política em uma Democracia Representativa Ocidental}

$\mathrm{O}$ regime de democracia representativa permite o desenvolvimento da cidadania e levanta questões acerca da conceituação de representatividade. Ele pressupõe um conjunto de instituições que disciplinam a participação popular no processo político, tais como as eleições, o sistema eleitoral, o sistema partidário e os demais elementos necessários à formação dos direitos políticos que qualificam a cidadania ${ }^{6}$. Nesse diapasão, o sistema político brasileiro adota um modelo partidário em que o sufrágio universal e o voto direto e secreto são

\footnotetext{
5 ARAÚJO, Clara. Por Que Uma Reforma Eleitoral Mais Ampla É Importante Para As Mulheres? Revista Gênero na Amazônia, nº 4, jul./dez., 2013. pp. 37-49.

6 SILVA. José Afonso da. Curso de Direito Constitucional Positivo. São Paulo: Malheiros Editores, 2011. p. 137
} 
a forma de escolher e legitimar a representação política e os partidos políticos são o canal que a viabiliza.

Os partidos políticos tornam-se assim imprescindíveis à obtenção de um cargo eletivo, uma vez que a Constituição Federal de 1988 determina que a representação política somente poderá ocorrer por intermédio dos partidos ${ }^{7}$, os quais apresentam-se como vetores de canalização da vontade política do povo ${ }^{8}$. Como veículos obrigatórios ao acesso a cargos eletivos representativos, os partidos tornam-se verdadeiros atores políticos coletivos, os quais possuem grande poder sobre as rotas de ingresso e inserção dos indivíduos no cenário político institucional.

Assim, a participação de grupos minoritários ${ }^{9}$ na esfera de representação parlamentar e/ou governamental, necessariamente, depende de uma ação positiva dos partidos políticos no sentido de inserção e incorporação interna de tais grupos e de acesso a oportunidades de concorrer a cargos eletivos. A seleção de candidatos no interior de um partido político irá depender de regras formais e gerais do sistema político-eleitoral nacional e de regras informais que regem a "cultura" interna partidária e o contexto no qual cada partido está disputando determinada eleição. Os "selecionadores" partidários, que são normalmente os dirigentes e membros de órgãos decisórios dos partidos, definem as estratégias e necessidades politicas centrais para dado contexto

\footnotetext{
${ }^{7}$ Constituição da República Federativa do Brasil de 1988, Art. 14. A soberania popular será exercida pelo sufrágio universal e pelo voto direto e secreto, com valor igual para todos, e, nos termos da lei, mediante: $\$ 3^{\circ}$ - São condições de elegibilidade, na forma da lei: V- a filiação partidária;

${ }^{8}$ Nesse sentido, García-Pelayo destaca que "só os partidos podem cumprir a função de transformar as orientações e atitudes políticas gerais vividas por certos setores da sociedade em programas de política nacional" (GARCIA-PELAYO, Manuel. El Estado de partidos. Madrid: Alianza, 1986. Pg. 77-78) 9 O conceito de minoria é tratado no presente trabalho através da perspectiva sociológica, pela qual se define minoria como um subgrupo existente dentro de uma sociedade que, em razão de característica étnicas, religiosas, culturais etc., são considerados diferentes do grupo maior/dominante e, por tais motivos, não possui os mesmos direitos ou oportunidades que o último e é alvo de discriminação ou preconceito. (BOUDON, Raymond e FRANÇOIS, Bourricaud. Dicionário crítico de sociologia. São Paulo: Ática. 1973. p. 342.)

, não sob o ponto de vista numérico de população e sim, no aspecto sociológico, no qual se define minoria como um subgrupo existente dentro de uma sociedade que se considera e/ou é considerado diferente do grupo maior e/ou dominante
} 
eleitoral e, com isso, definem o conjunto de indivíduos que irão compor a lista de competidores ${ }^{10}$.

Figura 1

Proporção de mulheres nos parlamentos: progresso na última década (médias regionais para 2005 e 2015)

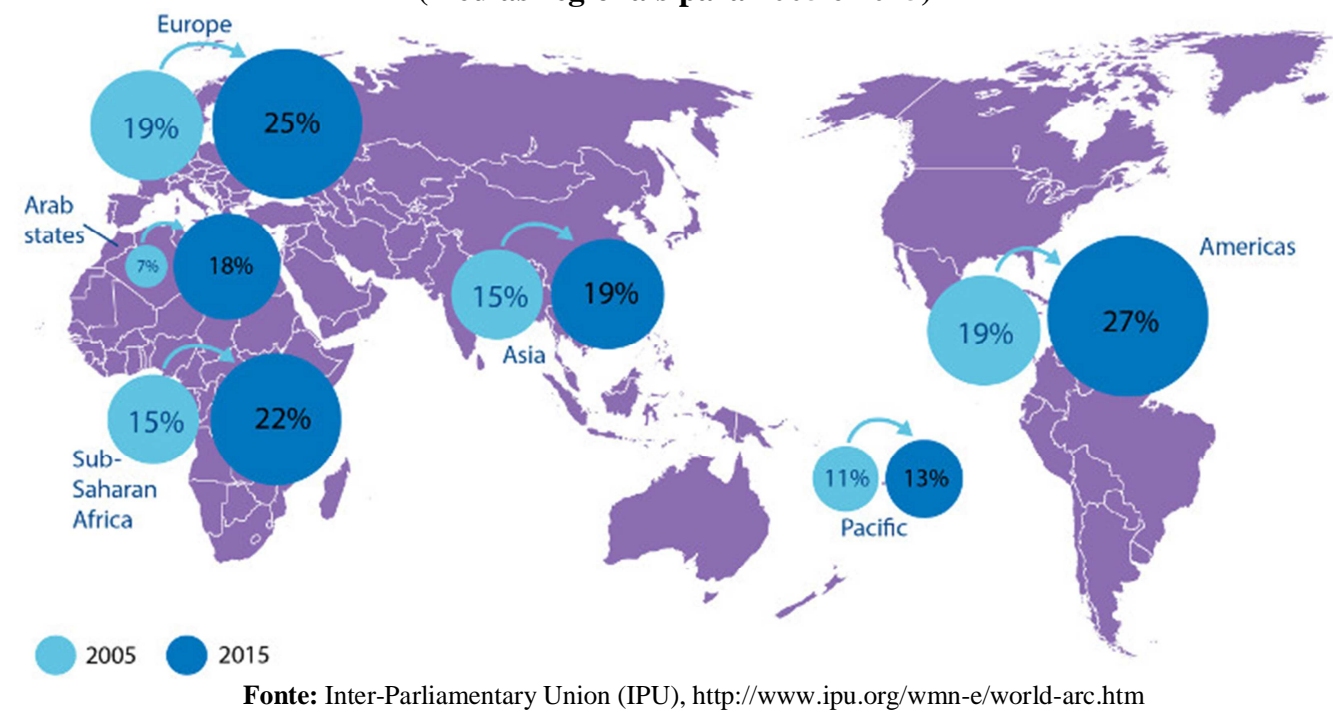

O papel dos partidos políticos torna-se evidente na compreensão dos fatores que contribuem para a baixa representação de mulheres em cargos eletivos no Brasil. Segundo dados da Inter-Parliamentary Union (IPU), nos últimos 10 anos, a participação feminina nos parlamentos nacionais ao redor do mundo cresceu de $15,7 \%$ em janeiro de 2005, para 22,1\% em janeiro de 2015, enquanto que no Brasil, o crescimento, no mesmo período de tempo, foi muito inferior, passando a representação feminina no Congresso Nacional de 9,09\% em 2005 para $9,59 \%$ em $2015^{11}$ (as médias regionais por continente podem ser verificadas na Figura 1 acima). Desse modo, conquanto o caso brasileiro guarde suas peculiaridades, ele está inserido em processos mais gerais que envolvem as democracias representativas contemporâneas em que a igualdade entre os gêneros no âmbito legislativo apresenta-se como um parâmetro para aferição do grau de amadurecimento político dos países e de

\footnotetext{
${ }^{10}$ ARAÚJO, Clara, e BORGES, Doriam. Trajetórias Políticas E Chances Eleitorais: Analisando O “Gênero" Das Candidaturas Em 2010. Revista de Sociologia e Política 21, nº. 46, 2013. pp. 69-91.

${ }^{11}$ Inter-Parliamentary Union and UN Women, "Women in Politics: 2015".
} 
seu comprometimento com as instituições democráticas, questionando-se a própria natureza da representação em debate ao constatar-se o desequilíbrio entre a proporcionalidade demográfica da mulher e sua presença nos parlamentos $^{12}$.

Partindo-se do conceito de que os partidos políticos influenciam e são influenciados pela cultura política e pelas características do sistema eleitoral, busca-se analisar aspectos endógenos e exógenos a tal sistema que influenciam as decisões dos indivíduos pertencentes a grupos minoritários de tornarem-se candidatos e o papel dos partidos como atores políticos que podem viabilizar ou obstaculizar o ingresso de tais indivíduos na vida política. Observando-se a perspectiva de gênero, a literatura tem apontado para certos elementos do contexto político que afetam o sistema partidário em geral, permitindo identificar tendências associadas a determinado sistema político em que a categoria gênero faz-se presente, de maneira direta ou indireta, antes mesmo do momento eleitoral em $\mathrm{si}^{13}$.

\subsection{Relação entre Sistemas Políticos de Representação Elegibilidade das Mulheres}

A relação entre sistema partidário e sistema eleitoral é intrínseca, de modo que a organização e as práticas partidárias somente podem ser compreendidas perpassando-se uma análise do sistema eleitoral. Embora o sistema partidário não se restrinja a representação política eleita, conquanto os partidos também realizem uma atividade de veiculação de ideias em relação à vida social e política local e nacional, as ações e decisões partidárias são orientadas, em última instância, pela busca de acesso ao poder, que concretiza-

\footnotetext{
12 ARAÚJO, Clara, e BORGES, Doriam. Trajetórias Políticas E Chances Eleitorais: Analisando O “Gênero" Das Candidaturas Em 2010. Revista de Sociologia e Política 21, nº. 46, 2013. pp. 69-91.

13 ARAÚJO, Clara. Partidos políticos e gênero: mediações nas rotas de ingresso das mulheres na representação política. Revista de Sociologia e Política, núm. 24, jun; 2005, pp. 193-215. Universidade Federal do Paraná, Curitiba, Brasil.
} 
se com a obtenção da representação parlamentar e/ou governamental ${ }^{14}$. Assim, o posicionamento e organização dos partidos políticos não se limita a análise de ideologias. Os cálculos eleitorais também são um fator fundamental para a definição das estratégias partidárias e do lugar dos atores políticos nas mesmas, abrangendo, inclusive, o processo de recrutamento e de investimento eleitorais.

O sistema eleitoral é o conjunto de técnicas e procedimentos utilizados na realização de um pleito eleitoral, destinado a organizar a representação da população no território nacional, incluindo o modo como este é dividido em distritos ou circunscrições, os procedimentos de apresentação de candidatos e de designação dos eleitos de acordo com os votos emitidos. ${ }^{15}$ Há três grandes "famílias" de sistemas eleitorais, definidos, sobretudo, pela forma de representação adotada para as chamadas Câmaras Baixas, que, no caso brasileiro, equivale à Câmara dos Deputados.

A primeira grande "família" é a dos Sistemas Majoritários, no Brasil conhecido como Sistema Distrital Puro. Embora possua variações internas, nesse sistema, em geral, no pleito eleitoral, cada partido político somente pode lançar um candidato para determinado território (distrito ou circunscrição) e a representação deste será feita pelo candidato (ou candidatos) que obtiver a maioria (absoluta ou relativa) dos votos válidos.

O segundo tipo de sistema são os Sistemas Proporcionais, em que, como o próprio nome indica, a natureza da representação é a proporcionalidade. Cada partido apresenta uma lista de candidatos ao eleitorado para cada território (distrito, região ou estado), ou ainda, como verificado em alguns casos, uma única lista nacional. Por meio de uma fórmula eleitoral, os representantes são eleitos em proporção ao número de votos

\footnotetext{
${ }^{14}$ ARAÚJO, Clara. Partidos políticos e gênero: mediações nas rotas de ingresso das mulheres na representação política. Revista de Sociologia e Política, núm. 24, jun; 2005, pp. 193-215. Universidade Federal do Paraná, Curitiba, Brasil.

15 SILVA. José Afonso da. Curso de Direito Constitucional Positivo. São Paulo: Malheiros Editores, 2011. p. 370
} 
recebidos pelo partido, buscando-se garantir que as minorias também possam ser representadas, desde que atingido determinado quociente eleitoral. As listas determinam a forma como os eleitores irão exercer sua autonomia na escolha de seus representantes, havendo três formas gerais de listas partidárias: fechadas, abertas ou flexíveis. No primeiro caso, o partido apresenta a lista com os candidatos em uma ordem preestabelecida, determinando-se um ranking de prioridade de nomes que não pode ser mudada, e o eleitor vota na legenda, sendo eleitos os candidatos de acordo com sua posição na lista ${ }^{16}$. Na segunda forma, o partido tem uma lista com candidatos, mas o eleitor, além de poder votar na legenda partidária, também pode escolher o candidato por nome, sendo eleitos os mais votados. Na terceira situação, vota-se na legenda, mas existem mecanismos de reordenamento de prioridades da lista apresentada pelo partido, votando-se na lista com indicação do nome preferido ou dar dois votos, um para a legenda e outro para um segundo nome ${ }^{17}$.

Por fim, o terceiro grupo é o dos Sistemas Mistos, ou Distrital Misto, conforme denominação brasileira. Resguardando-se suas variações internas, resumidamente, esses sistemas buscam combinar aspectos do Sistema Majoritário e do Sistema Proporcional. Os distritos ou circunscrições são divididos e sobrepostos em duas partes, uma majoritária e outra proporcional, de modo que, em geral, o eleitor vota duas vezes, observando-se as regras específicas de cada um dos dois sistemas anteriormente mencionados.

Em relação aos diferentes sistemas políticos de representação e sua articulação com a elegibilidade das mulheres, segundo o Banco de Dados de Cotas para Mulheres, e conforme pode ser observado na Figura 2, há

\footnotetext{
16 ARAÚJO, Clara. Por Que Uma Reforma Eleitoral Mais Ampla É Importante Para As Mulheres? Revista Gênero na Amazônia, nº 4, jul./dez., 2013. pp. 37-49.

17 ARAÚJO, Clara. Por que Uma Reforma Eleitoral Mais Ampla É Importante Para As Mulheres? Revista Gênero na Amazônia, no 4, jul./dez., 2013. pp. 37-49.
} 
evidências de que os Sistemas Proporcionais são mais favoráveis às mulheres, seguidos dos Sistemas Mistos e, por último, dos Sistemas Majoritários ${ }^{18}$.

Figura 2

Proporção média de mulheres eleitas nos diferentes Sistemas Eleitorais ao redor do mundo.
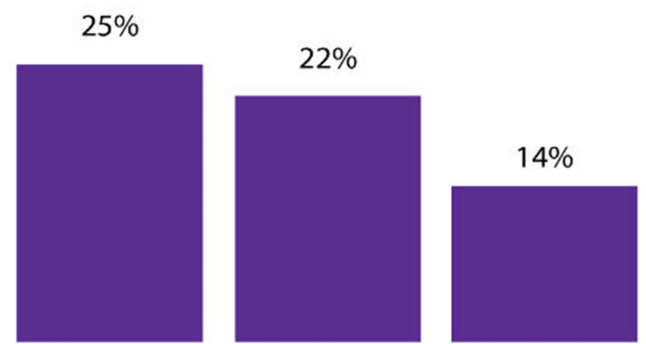

SISTEMAS

SISTEMAS PROPORCIONAIS MISTOS

SISTEMAS Fonte: Inter-Parliamentary Union (IPU), http://www.ipu.org/wmn-e/world-arc.htm

No Brasil, as eleições para a Câmara dos Deputados, Assembleias Legislativas, Câmara Distrital e Câmaras de Vereadores são feitas pelo Sistema Proporcional, enquanto que os demais cargos são eleitos no Sistema Majoritário. Alguns fatores podem ser apontados como razões pelas quais o sistema proporcional apresenta-se como mais propício a melhor representatividade de gêneros.

No Sistema Proporcional, cada partido apresenta uma lista de candidatos para cada circunscrição, e as listas partidárias, em geral, comportam vários nomes - no Brasil, por exemplo, cada partido pode registrar candidatos na razão de até $150 \%$ do número de vagas a serem preenchidas ${ }^{19}$. Por esse motivo, o partido ou coligação partidária tende a incluir candidatos que representem diversas configurações sociais, para tentar maximizar o apelo

18 Dentre os 126 países constantes no Banco de Dados de Cotas para Mulheres (http://www.quotaproject.org/), elaborada por IDEA, IPU e Universidade de Estocolmo, naqueles que adotam Sistemas Proporcionais, as mulheres atualmente possuem em média 26\% dos assentos das Câmaras Baixas ou Únicas, enquanto nos que utilizam Sistema Majoritário, a presença média feminina é de $17 \%$ e, nos Sistemas Mistos, de 21\%. No mesmo sentido, dos 14 países que possuem $10 \%$ ou menos de deputadas mulheres, 8 adotam o Sistema Majoritário (Botsuana, Brazzaville (República do Congo), Haiti, Ilhas Salomão, Líbano, Mali, Samoa e Suazilândia), 2 o Sistema Proporcional (Brasil e Sri Lanka), 3 adotam o Sistema Misto (Egito, Hungria e República Democrática do Congo) e 1 adota um sistema próprio (Vanuatu).

${ }^{19}$ Lei $n^{\circ}$ 9.504/1997, art. 10. Cada partido poderá registrar candidatos para a Câmara dos Deputados, Câmara Legislativa, Assembleias Legislativas e Câmaras Municipais, até cento e cinquenta por cento do número de lugares a preencher. 
coletivo ao eleitorado nos diferentes grupos sociais ${ }^{20}$. A inclusão de diferentes perfis que se apresentem como relevantes torna-se atraente para os partidos, pois isso também se traduz em soma de votos para a legenda, contribuindo para o aumento da chance de obtenção do quociente eleitoral.

Já no Sistema Majoritário, como cada partido seleciona um único candidato por cargo, os "selecionadores" partidários tendem a indicar candidatos que maximizem as chances e minimizem os riscos eleitorais. Supõe-se que candidatos que já tenham sido eleitos anteriormente e que efetivamente ocupem cargos parlamentares, ou que ao menos obtiveram resultados significativos em pleitos anteriores, tendem a oferecer menor risco na competição. Além disso, os dirigentes partidários buscam candidatos que componham o perfil tradicional de seus representantes, que são identificados com os padrões dos usualmente eleitos pelos partidos. Esse sistema de escolha apresenta-se prejudicial para as mulheres pois, por motivos históricos, aqueles que já estão eleitos ou têm histórico partidário são, predominantemente, homens ${ }^{21}$.

Nos Sistemas Majoritários, em geral, há poucos e grandes partidos competindo no pleito eleitoral, muitas vezes caracterizando-se um bipartidarismo, compreendido por partidos com perfis de elegibilidade mais tradicionais e consolidados, sendo o ingresso de setores historicamente excluídos mais difícil. Enquanto nos Sistemas Proporcionais, em que um candidato é eleito com menor número de votos, o multipartidarismo é incentivado, do que decorre o surgimento de partidos com diferentes perfis ideológicos e que se mostram mais receptivos ao ingresso de grupos minoritários. A diferença de quantidade de partidos também se apresenta como

\footnotetext{
20 ARAÚJO, Clara. Partidos políticos e gênero: mediações nas rotas de ingresso das mulheres na representação política. Revista de Sociologia e Política, núm. 24, jun; 2005, pp. 193-215. Universidade Federal do Paraná, Curitiba, Brasil.

21 ARAÚJO, Clara. Partidos políticos e gênero: mediações nas rotas de ingresso das mulheres na representação política. Revista de Sociologia e Política, núm. 24, jun; 2005, pp. 193-215. Universidade Federal do Paraná, Curitiba, Brasil.
} 
uma vantagem para a adoção do Sistema Proporcional à medida que este favorece o "efeito-contágio", em que determinada iniciativa de um partido, quando surte efeito positivo, tende a ser, em razão de seu apelo eleitoral, incorporada pelos outros partidos, uma vez que suas ideologias não são tão polarizadas quanto em um sistema com menos partidos.

Por fim, o Sistema Proporcional, por possuir uma pluralidade mínima de candidatos concorrendo, também torna viável a adoção de estratégias de ação de discriminação positiva, tais como as cotas legislativas ou de assentos parlamentares, sobre as quais falaremos em capítulo específico. Observa-se ainda que os sistemas mistos apresentam internamente resultados semelhantes aos apresentados anteriormente, de modo que mais mulheres têm sido eleitas por meio das listas partidárias (aspectos proporcionais do sistema) do que por meio de distritos majoritários ou uninominais. ${ }^{22}$

Como resultado, enquanto nos Sistemas Majoritários a dificuldade das mulheres reside em um primeiro momento em conseguir serem indicadas candidatas, nos Sistemas Proporcionais, o obstáculo apresenta-se na obtenção de condições efetivas de competir no pleito eleitoral. Esse obstáculo manifestase de forma diferente a depender do tipo de lista contemplado pelo Sistema Proporcional. No sistema de lista fechada, o desafio consiste em ocupar um lugar no topo de preferências da lista de candidatura do partido. No de lista aberta, em obter prioridade nos recursos e investimentos partidários.

\subsection{Relação entre Sistemas Partidários e Elegibilidade das Mulheres}

Os sistemas partidários são classificados quanto à quantidade de partidos políticos com significativas condições de alcançar o poder político, podendo ser: bipartidário, multi ou pluripartidário, ou com um partido único. $\mathrm{O}$

22 ARAÚJO, Clara. Partidos políticos e gênero: mediações nas rotas de ingresso das mulheres na representação política. Revista de Sociologia e Política, núm. 24, jun; 2005, pp. 193-215. Universidade Federal do Paraná, Curitiba, Brasil. 
primeiro sistema é mais simples, com o predomínio de dois partidos, e é considerado um modelo estável e eficaz quanto à administração pública. $\mathrm{O}$ segundo, marcado pela presença de vários partidos com possibilidades reais de atingir uma posição de poder, surge como forma de possibilitar a representação de interesses mais diversos, incluindo minoritários, e apresenta-se como a tendência atual de legitimação da democracia. O último modelo é marcado como aquele em que um único partido conquista postos suficientes para governar sozinho, sendo frequentemente ligado a regimes autoritários. ${ }^{23}$

Com a existência de coligações partidárias, a distinção entre o bipartidarismo e o multipartidarismo torna-se mais tênue, dada a existência de pequenos grupos ao lado de grandes partidos e até mesmo a formação de alianças entre grandes partidos. No entanto, não há propriamente um consenso ou padrões claros acerca de como a natureza do sistema partidário afeta a eleição de mulheres. Seguindo o raciocínio apresentado anteriormente, o pluripartidarismo tenderia a apresentar uma proporção mais elevada de mulheres eleitas, uma vez que o "mercado eleitoral" seria estimulado e o surgimento de novos partidos absorveria novos atores sociais. ${ }^{24}$ Em contrapartida, um sistema com poucos e grandes partidos reduziria as oportunidades para os grupos que tradicionalmente se encontram fora do campo de representação política, posto que as bases de apoio já se encontrariam consolidadas e os padrões de recrutamento eleitorais já estabelecidos tenderiam a se perpetuar.

Entretanto, há divergências quanto ao impacto da fragmentação partidária sobre o sistema político, questionando-se se, a partir de determinada intensidade, com o surgimento de um número elevado de partidos, ela se

\footnotetext{
23 LIPJHART, Arend. Modelos de democracia. Rio de Janeiro: Ed. Civilização Brasileira, 2003. (p. 85-111)

24 ARAÚJO, Clara. Partidos políticos e gênero: mediações nas rotas de ingresso das mulheres na representação política. Revista de Sociologia e Política, núm. 24, jun; 2005, pp. 193-215. Universidade Federal do Paraná, Curitiba, Brasil.
} 
tornaria nociva ao sistema de representação, o que permitiria, por exemplo, que parlamentares com menos de $1 \%$ dos votos válidos fossem eleitos. ${ }^{25,26}$ Críticos também apontam que a mera proliferação de partidos não é suficiente para promover a diversidade de atores no âmbito político, sendo necessário que tal aumento da diversidade dos partidos se dê pelo surgimento de partidos progressistas, posto que a criação de partidos tradicionalistas, sobretudo os de corte religioso, não tenderiam a incorporar novos agentes, incluindo mulheres. No mesmo sentido, favorecendo um sistema com menos partidos, encontra-se a posição de que o multipartidarismo exagerado é marcado não só pelo constante surgimento de novas agremiações, mas como pela dissolução destas, de modo que um cenário de instabilidade é criado, tornando as condições adversas para o crescimento político de potenciais candidatas. ${ }^{27}$

Um estudo comparado realizado em 1997 pela Inter Paliamentary Union (IPU) envolvendo diversos países europeus ${ }^{28}$ constatou que havia dois padrões de elegibilidade partidária em relação às mulheres, um quanto à ideologia partidária e outro quanto à magnitude do partido: os partidos de médio porte tenderiam a eleger mais mulheres do que partidos grandes ou muito pequenos. Nesse sentido, partidos muito grandes gerariam um custo eleitoral muito elevado de competição intrapartidária entre candidatos, o que dificultaria o acesso de novos atores, enquanto partidos muito pequenos tenderiam a dar prioridade eleitoral a seus dirigentes, em geral homens, posto que sua ambição se restringe a alcançar um pequeno número de vagas.

\footnotetext{
${ }^{25}$ TAVARES, José Giusti. Sistemas eleitorais e federação no Brasil: as lições da Alemanha. Texto apresentado na Conferência Internacional "Reforma política no Brasil em perspectiva comparada" realizado em junho de 2002 no Rio de Janeiro.

${ }^{26}$ Só no Rio de Janeiro, nas eleições de 2014, 21 dos 46 deputados federais foram eleitos com menos de $1 \%$ dos votos válidos. Dados do TSE.

27 ARAÚJO, Clara. Partidos políticos e gênero: mediações nas rotas de ingresso das mulheres na representação política. Revista de Sociologia e Política, núm. 24, jun; 2005, pp. 193-215. Universidade Federal do Paraná, Curitiba, Brasil.

28 Inter-Parliamentary Union. Men and women in politics: democracy still in the making. A comparative study. Report and documents n. 28. Genéva: Inter-Parliamentary Union. 1997.
} 
Atualmente, o Brasil possui 32 partidos políticos registrados no Tribunal Superior Eleitoral $^{29}$, dos quais, após as eleições gerais de 2014, 28 alcançaram representação no Congresso Nacional, de modo que o sistema partidário brasileiro afirma-se patentemente como pluripartidário. As 51 mulheres eleitas para a Câmara dos Deputados estão distribuídas por 17 partidos, sendo que 23 deputadas foram eleitas por um dos cinco maiores partidos nacionais ${ }^{30}$. Desse modo, infere-se que, no Brasil, candidatar-se por um grande partido tende a resultar em maiores chances de uma mulher ser eleita. Quanto ao viés ideológico, dos cinco partidos que mais elegeram mulheres, três posicionam-se como partidos de esquerda, um de centro e um de $\operatorname{direita}^{31}$

Se observarmos o cenário das candidaturas, os partidos denominados de "nanicos" tendem a apresentar elevado percentual de candidatas quando comparados aos partidos maiores. ${ }^{32,33}$ Contudo, a elegibilidade das mulheres nesses partidos é muito pequena. Nas eleições gerais de 2014, por exemplo, apenas cinco, das 51 deputadas federais, foram eleitas por partidos muito pequenos $^{34}$.

Como foi assinalado, o processo de recrutamento eleitoral e acolhida das mulheres é permeado por variáveis internas e externas ao partido e ao próprio sistema eleitoral, perpassando por fatores institucionais, partidários e pessoais, envolvendo desde as motivações individuais para candidatar-se até a

\footnotetext{
${ }^{29}$ Informação disponível em http://www.tse.jus.br/partidos/partidos-politicos/registrados-no-tse acesso em 10/04/2015.

${ }^{30} \mathrm{PT}, \mathrm{PMDB}, \mathrm{PSDB}, \mathrm{PSD}$ e PP.

${ }^{31}$ Os referidos partidos são PT (9 deputadas eleitas), PSB (5 deputadas eleitas) e PCdoB (4 deputadas eleitas) como partidos de esquerda; PMDB (7 deputadas eleitas) como partido de centro; e PSDB (5 deputadas eleitas) como partido de direita.

32 Informação disponível em http://www.tse.jus.br/eleicoes/estatisticas/estatisticas-eleitorais-2014resultado. Quantitativo de candidatos por cargo/partido/coligação/sexo. Acessado em 10/04/2015.

${ }^{33}$ Nas eleições de 2014, por exemplo, os únicos partidos que apresentaram $50 \%$ ou mais de candidatas mulheres concorrendo nas eleições para deputado federal, possuíam menos de 10 candidatos concorrendo ao cargo.

${ }^{34}$ PTN (2 deputadas eleitas), PTC, PMN e PV (cada um com 1 deputada eleita).
} 
possibilidade de ser indicada pelo partido. Conquistar cargos políticos na estrutura organizacional do Estado envolve o domínio de uma complexa cadeia de relações de interesses de diversas naturezas, o que implica, na maioria dos casos, em um cálculo pragmático da correlação de potencial eletivo do candidato com os objetivos e as estratégias partidárias em uma determinada eleição. Nesse sentido, é realizada uma análise pelo partido que envolve posições ideológicas e interesses do mesmo e de investidores em financiar determinadas campanhas eleitorais, criando-se ou não um compromisso do partido com a busca da eleição de seu candidato.

Neste capítulo foram abordados os aspectos mais gerais do sistema político-eleitoral e sua relação com o sistema partidário e as condicionantes desses sistemas que interferem nas chances de as mulheres disputarem eleições e serem eleitas - fatores que podem ser considerados exógenos aos partidos. No próximo capítulo, a análise será dirigida às dimensões internas dos partidos, abordando seus aspectos organizacionais e ideológicos e o compromisso político-partidário com a igualdade de gênero. 


\section{CAPÍTULO II - CONTEXTOS PARTIDÁRIOS - PERFIS IDEOLÓGICOS E ORGANIZACIONAIS - RECRUTAMENTO ELEITORAL E ESTRATÉGIAS DE PROMOÇÃO DE PARIDADE DE GÊNERO}

O contexto partidário e suas dimensões internas, sobretudo no que tange aos aspectos organizacionais e ideológicos, exercem forte influência sobre o processo de recrutamento eleitoral e sobre as chances de grupos minoritários, incluindo-se nestes as mulheres, de alcançarem cargos de significância política. Como os partidos políticos no Brasil são sociologicamente distintos, presumese que, em tese, cada partido deve possuir diferentes maneiras de se organizar internamente e, consequentemente, adotam estratégias e mecanismos próprios na realização de seu processo de seleção e recrutamento eleitoral. No nível intrapartidário, os problemas centrais consistem em identificar o local e o escopo do processo de tomada de decisão partidária, analisando o modo como cada partido lida concretamente com a questão da representação, e as diferentes capacidades dos partidos de absorver demandas igualitárias, no caso, de paridade de gênero na política ${ }^{35}$.

Tido como um dos papéis clássicos dos partidos políticos, o recrutamento eleitoral não é somente uma questão de determinar quem será elegível para cargos representativos, mas também de indicar candidatos para os postos políticos em todos os níveis do governo e em agências federais, atribuindo-se assim, aos partidos, a função secundária de preencher uma ampla gama de posições políticas nomeadas por meio de indicação ${ }^{36}$. Considerando que as estratégias eleitorais partidárias envolvem trajetórias, recursos financeiros e obstáculos culturais e sociais, encontra-se suporte no "Modelo de

\footnotetext{
35 COSTA, Luiz Domingos, BOLOGNESI, Bruno e CODATO, Adriano. Variáveis sobre o recrutamento político e a questão de gênero no Parlamento brasileiro. Working Papers/Textos para Discussão, núm. 7, mai, 2013. (Acessível em: "http://observatory-elites.org/wpcontent/uploads/2012/06/wp-observatory-n.7-2013.pdf')

${ }^{36}$ NORRIS, Pippa. Recrutamento Político. In: CROTTY, W. \& KATZ, R. S. (eds) Handbook of Party Politics. Londres: Sage, 2006. Tradução de BOLOGNESI, Bruno.
} 
processo do recrutamento político"37 elaborado pela professora Pippa Norris, da Universidade de Harvard, para se compreender o funcionamento do recrutamento político, respondendo a três perguntas: i) quem pode ser eleito; ii) quem escolhe dentre os elegíveis os que irão competir no pleito eleitoral; e iii) quem é selecionado.

Identificando os principais fatores que influenciam o processo de recrutamento de candidatos, a autora parte de um conceito de demanda (dos partidos visando a composição de suas listas) e oferta (de indivíduos disponíveis e potencialmente elegíveis), e sugere a existência de três fases sucessivas, conforme ilustrado na Figura 3: (i) a certificação, envolvendo a legislação eleitoral, as regras internas partidárias e normas sociais informais, que determinam se uma candidatura é elegível; (ii) a indicação, envolvendo os interesses diretos de oferta e demanda; e (iii) a eleição, com a determinação efetiva de quem ocupará o cargo eletivo. ${ }^{38}$

Figura 3

Modelo de Norris do Processo de Seleção de Candidatos

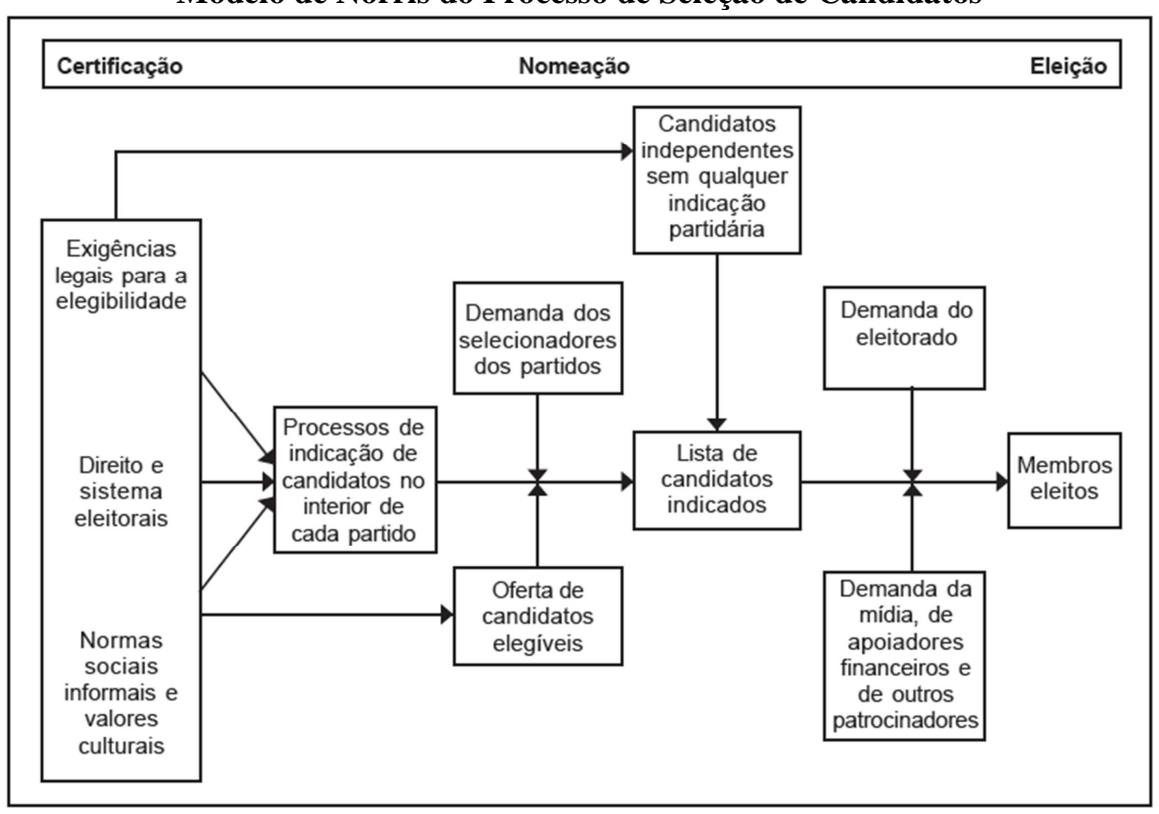

Fonte: Norris (2006), traduzido por Bruno Bolognesi

${ }^{37}$ NORRIS, Pippa, e LOVENDUSKI, Joni. Gender and Party Politics. Londres: Sage, 1993.

38 NORRIS, Pippa. Recruitment. In: CROTTY, W. \& KATZ, R. S. (eds) Handbook of Party Politics. Londres: Sage, 2006. Tradução de BOLOGNESI, Bruno. In: Revista de Sociologia e Política 21, nº. 46, 2013. pp. 11-32. 
Demanda e oferta ocorrem e realizam-se no contexto específico de cada disputa eleitoral. A oferta apresenta-se para os partidos políticos como um pool de elegíveis, em que cada candidatura individual é analisada com base em uma série de aspectos, como sua origem social e público alvo eleitoral, suas motivações para candidatar-se e seu capital político, de modo que os selecionadores poderão identificar dentro do conjunto de competidores, aqueles que reúnem mais condições e mais chances de serem eleitos ${ }^{39}$. No lado da demanda, juntamente com os requerimentos legais, outras exigências de certificação e indicação são impostas pelos partidos políticos por meio de seus estatutos, programas e normas e culturas internas ${ }^{40}$ - as "regras definidoras da seleção" - e pelos próprios selecionadores, aqueles que, em geral, são dirigentes e membros de órgãos decisórios dos partidos e que, portanto, definem as estratégias e necessidades políticas centrais do partido a cada disputa eleitoral ${ }^{41}$.

Com base nos aspectos destacados e posicionando-se no cenário mais amplo do sistema político e da própria competição legislativa em si, o partido político define o conjunto de indivíduos que comporá a lista de competidores. Paralelamente a esse processo de certificação e indicação, os partidos políticos, ao fornecerem redes sociais, treinamento e experiência organizacional, modelam a "oferta" de seus candidatos em potencial, realizando aquilo que Bacharach e Baratz ${ }^{42}$ chamaram de "não-decisão", uma vez que determinados grupos minoritários são desencorajados, por regras formais ou informais

\footnotetext{
39 ARAÚJO, Clara, e BORGES, Doriam. Trajetórias Políticas E Chances Eleitorais: Analisando O “Gênero" Das Candidaturas Em 2010. Revista de Sociologia e Política 21, nº 46, 2013. pp. 69-91.

${ }^{40}$ NORRIS, Pippa. Recrutamento Político. In: CROTTY, W. \& KATZ, R. S. (eds) Handbook of Party Politics. Londres: Sage, 2006. Tradução de BOLOGNESI, Bruno.

${ }^{41}$ ARAÚJO, Clara, e BORGES, Doriam. Trajetórias Políticas E Chances Eleitorais: Analisando $O$ “Gênero" Das Candidaturas Em 2010. Revista de Sociologia e Política 21, nº. 46, 2013. pp. 69-91.

42 BACHARACH, Peter e BARATZ, Morton S. Decisions and Non-Decisions: An Analytical Framework. American Political Science Review. Washington (DC), v. 57, n.3, p. 632-642, sept., 1963. In: NORRIS, Pippa. Recrutamento Político. In: CROTTY, W. \& KATZ, R. S. (eds) Handbook of Party Politics. Londres: Sage, 2006. Tradução de BOLOGNESI, Bruno.
} 
partidárias, a participar de um pleito político e perseguir uma carreira eletiva ${ }^{43}$. Alguns aspectos interiores ao sistema partidário, quando observados na perspectiva de gênero, operam para viabilizar ou obstaculizar o ingresso de mulheres nos cargos legislativos - nessa análise intrapartidária, destacam-se como relevantes a cultura organizacional e a ideologia de cada partido.

\subsection{A Dimensão Organizacional}

Os partidos políticos não são instituições fixas e imutáveis, estando em constante fluxo de adequação aos novos contextos políticos em que se vinculam e disputam um determinado pleito eleitoral. Regidos institucionalmente por estatutos, programas e demais normas internas, os partidos, nas democracias liberais modernas, por via de regra, determinam seus próprios métodos de escolha de candidatos, de modo que adoção de processos menos ou mais democráticos fica a cargo do próprio partido ${ }^{44,45}$. Nesse sentido, o nível de institucionalização do partido, seu grau e tipo de organização interna, a perenidade e a homogeneidade de suas práticas são fatores que influenciam o processo de recrutamento eleitoral e afetam as chances de inserção de mulheres e de outros setores que tradicionalmente não compõe a elite política ${ }^{46}$.

Há uma grande variação nas características organizacionais partidárias, mas é possível encontrar certa homogeneidade em torno de determinados padrões, partindo-se da análise de duas dimensões: (i) o grau de

\footnotetext{
${ }^{43}$ NORRIS, Pippa. Recrutamento Político. In: CROTTY, W. \& KATZ, R. S. (eds) Handbook of Party Politics. Londres: Sage, 2006. Tradução de BOLOGNESI, Bruno.

${ }^{44}$ NORRIS, Pippa. Recrutamento Político. In: CROTTY, W. \& KATZ, R. S. (eds) Handbook of Party Politics. Londres: Sage, 2006. Tradução de BOLOGNESI, Bruno.

${ }^{45}$ No Brasil, até 1995, o sistema eleitoral brasileiro, regulamentado pela Lei ${ }^{\circ}$ 5.682/1971, determinava um processo uniforme entre todos os partidos para a indicação de candidatos. Com o advento da Lei ${ }^{\circ}$ 9.096/1995, excluiu-se da legislação nacional o processo de indicação de candidatos, formalizando-se a autonomia dos partidos para estabelecer suas próprias regras no interior de seus estatutos.

${ }^{46}$ ARAÚJO, Clara, e ALVES, José Eustáquio Diniz. Impactos de Indicadores Sociais e do Sistema Eleitoral sobre as Chances das Mulheres nas Eleições e suas Interações com as Cotas. Revista de Ciências Sociais, Rio de Janeiro, Vol. 50, n 3, 2007. pp. 535 a 577.
} 
institucionalização das regras internas do partido; e (ii) o grau de centralização dos processos decisórios ${ }^{47}$. No que tange à dimensão institucional, refere-se à organização orgânico-estrutural do partido, ou seja, como são determinados os seus procedimentos internos e como suas regras internas são estabelecidas, formalizadas e conduzidas de maneira sistemática, de forma que o processo de seleção de candidatos pode ser regido por regras menos ou mais formais ou informais ${ }^{48}$. Em relação à centralização, o sistema pode ser mais centralizado ou mais localizado, determinando o quanto as decisões sobre candidaturas e postos de direção são tomadas, principalmente, pela liderança partidária nacional, ou são remetidas para órgãos regionais, distritais ou locais ${ }^{49}$.

Nos partidos em que predominam um maior grau de institucionalização, o processo de recrutamento eleitoral é orientado por regras mais formais que possuem publicidade e transparência e são acessíveis ao público em geral e, especialmente, ao conjunto de integrantes do partido. Regras e procedimentos explícitos de nomeação permitem o planejamento prévio de aspirantes a candidatos para definição de estratégias, assim como fazem com que qualquer tentativa de alteração das regras por parte de dirigentes seja mais facilmente identificada e passível de questionamento. Por outro lado, nos partidos em que o predomínio é o da informalidade, instaura-se uma cultura de decisões mais personalizadas ${ }^{50}$, em que as regras e critérios tendem a ser definidos

\footnotetext{
${ }^{47}$ NORRIS, Pippa. Recrutamento Politico. In: CROTTY, W. \& KATZ, R. S. (eds) Handbook of Party Politics. Londres: Sage, 2006. Tradução de BOLOGNESI, Bruno.

48 ARAÚJO, Clara. Partidos políticos e gênero: mediações nas rotas de ingresso das mulheres na representação política. Revista de Sociologia e Política, núm. 24, jun;, 2005, pp. 193-215. Universidade Federal do Paraná, Curitiba, Brasil.

49 ÁLVARES, Maria Luzia Miranda. Mulheres Brasileiras em Tempo de Competição Eleitoral: Seleção de Candidaturas e Degraus de Acesso aos Cargos Parlamentares. DADOS - Revista de Ciências Sociais, Rio de Janeiro, Vol. 51, nº4, 2008, pp. 895 a 939.

50 Nesse sentido Norris e Lovenduski observam que "se os líderes partidários são simpáticos à necessidade de promover a igualdade de gênero, por exemplo, se eles desejam atrair mais mulheres eleitoras, eles têm considerável poder para fazê-lo. Através da patronagem, eles podem melhorar a posição das mulheres nas listas partidárias ou lugares em bons distritos", destacando-se que, sem salvaguardas institucionalizadas, a dependência da "simpatia" das lideranças partidárias faz com que quaisquer ganhos possam ser rapidamente invertidos. (NORRIS, Pippa, e LOVENDUSKI, Joni. Gender and Party Politics. Londres: Sage, 1993. P. 323)
} 
casuisticamente pelos tomadores de decisão, constituindo um processo relativamente fechado, tornando-o suscetível a práticas "personalistas",51 e a influências externas ao conteúdo pragmático do partido ${ }^{52}$. Nesse sentido, a institucionalização tende a ser favorável aos novos atores que queiram ingressar na vida política e na competição eleitoral.

A institucionalização também se reflete no modo como os partidos organizam-se organicamente, com a estruturação e articulação partidária dos níveis nacional ao local, estabelecendo-se regras claras quanto ao papel de cada instância. Sobre esse aspecto, avalia-se a coesão e disciplina partidárias, buscando-se constatar a existência ou não de uma nacionalização partidária. No Brasil, verifica-se que há, em geral, um hiato entre os objetivos programáticos no plano nacional e os objetivos contextuais localizados, produzindo uma espécie de segmentação intrapartidária, constatada, inclusive, pelas alianças e coligações distintas, e frequentemente contraditórias, feitas nos planos nacional e locais ${ }^{53}$. Tal debilidade no grau de nacionalização dos partidos dificulta a implementação de políticas de gênero no interior do partido de maneira mais sistemática e eficaz.

Quanto ao grau de centralização ou descentralização dos processos partidários, o locus da tomada de decisão varia desde a mais centralizada, com os órgãos nacionais controlando o processo de seleção de candidatos completamente, até a mais local, com o uso de cédulas de votação por todos os filiados aos partidos ${ }^{54}$. Diferentemente do vetor de institucionalização, não há

\footnotetext{
${ }^{51} \mathrm{O}$ personalismo é marcado pela prática de alguns partidos políticos em que seus costumes e normas utilizam-se da mediação de lideranças individuais ao lidar com o eleitorado em geral, de modo que se enfraquece a dimensão coletiva das instituições partidárias e incentiva-se práticas de patronagem e clientelismo como meio de acesso a direitos.

52 ARAÚJO, Clara. Partidos políticos e gênero: mediações nas rotas de ingresso das mulheres na representação política. Revista de Sociologia e Política, núm. 24, jun; 2005, pp. 193-215. Universidade Federal do Paraná, Curitiba, Brasil.

53 ARAÚJO, Clara. Partidos políticos e gênero: mediações nas rotas de ingresso das mulheres na representação política. Revista de Sociologia e Política, núm. 24, jun; 2005, pp. 193-215. Universidade Federal do Paraná, Curitiba, Brasil.

${ }^{54}$ NORRIS, Pippa. Recrutamento Político. In: CROTTY, W. \& KATZ, R. S. (eds) Handbook of Party Politics. Londres: Sage, 2006. Tradução de BOLOGNESI, Bruno.
} 
muito consenso na literatura sobre o grau em que um sistema mais centralizado ou localizado isoladamente pode ser mais favorável ao acesso de mulheres à representação política ${ }^{55}$. Alguns autores, como Norris, tendem a ver em um sistema descentralizado, desde que formal, mais chances de setores fora da elite partidária influenciarem os processos de seleção, apontando que partidos com alto grau de centralização podem ser pouco maleáveis quanto a adequações regionais necessárias e dinâmicas eleitorais favoráveis a novos atores, inclusive as mulheres ${ }^{56}$. De outro lado, autores como Guadagnini ${ }^{57}$ observam que a centralização de decisões em órgãos nacionais estruturados, com critérios pré-fixados a serem observados, facilitam a movimentação interna desses novos atores que não compõem a elite dirigente, viabilizando a superação de interesses locais que tenderiam a predominar em decisões mais regionalizadas.

\subsection{A Dimensão Ideológica}

No que diz respeito à dimensão ideológica, é possível distribuir os partidos políticos pelo tradicional continuum direita-centro-esquerda, e a literatura indica que partidos de esquerda tendem a estimular mais a participação política das mulheres e, com isso, ampliam suas chances de eleição $^{58}$. Tradicionalmente, foram os partidos de esquerda os primeiros a

\footnotetext{
55 ARAÚJO, Clara. Partidos políticos e gênero: mediações nas rotas de ingresso das mulheres na representação política. Revista de Sociologia e Política, núm. 24, jun;, 2005, pp. 193-215. Universidade Federal do Paraná, Curitiba, Brasil.

${ }^{56}$ Adicionalmente, destaca-se que a própria composição das direções partidárias apresenta uma baixa presença de mulheres. Exemplificativamente, dos 32 partidos registrados junto ao TSE, apenas 2 possuem Presidentes Nacionais mulheres, e nenhum possui o cargo de Secretário-Geral ocupado por uma mulher. (dados encontrados em http://www.tse.jus.br/partidos/partidos-politicos/orgao-partidario busca por Relatório de Membros por Cargo - acesso em 09 de maio de 2015)

${ }^{57}$ GUADAGNINI, Marila. A "Partitocrazia" without Women: The Case of Italian Party System. In: LOVENDUSKI, Joni e NORRIS, Pippa. Women and Politics. Oxford: Oxford Univerisity. 1996. apud ARAÚJO, Clara. Partidos políticos e gênero: mediações nas rotas de ingresso das mulheres na representação política. Revista de Sociologia e Política, núm. 24, jun;, 2005, pp. 193-215. Universidade Federal do Paraná, Curitiba, Brasil.

${ }^{58}$ ARAÚJO, Clara, e ALVES, José Eustáquio Diniz. Impactos de Indicadores Sociais e do Sistema Eleitoral sobre as Chances das Mulheres nas Eleições e suas Interações com as Cotas. Revista de Ciências Sociais, Rio de Janeiro, Vol. 50, n 3, 2007. pp. 535 a 577.
} 
incluir algum tipo de norma interna voltada para a ampliação da participação das mulheres. No Brasil, por exemplo, o Partido dos Trabalhadores (PT), em 1991, foi o primeiro partido a adotar cotas de gênero para os cargos de direção partidária $^{59}$. Entretanto, sobretudo a partir da década de 1990, verificou-se nas democracias modernas, uma disseminação de iniciativas e de inclusão do tema de igualdade de representação nas agendas de partidos de outros espectros ideológicos, inclusive nos de corte mais conservador, ocorrendo o anteriormente mencionado "efeito contágio".

As derrotas eleitorais operaram como elemento de estímulo a mudanças nas políticas partidárias, uma vez que os partidos se viram obrigados a reavaliar o peso do eleitorado feminino e a assumir posturas mais abertas a causa das mulheres. Com base na análise das tentativas de respostas dos partidos a tais demandas, Lovenduski, em levantamento envolvendo as iniciativas de partidos de diferentes ideologias em diversos países ${ }^{60}$, identificou três tipos básicos de estratégias usualmente adotadas, indicando distintos níveis de compromisso com a igualdade de gênero. Com modificações realizadas por Norris, alterando algumas designações e ampliando a abrangência da análise para englobar políticas que não-necessariamente dependem das iniciativas dos partidos, as estratégias de promoção de paridade de gênero na representação política são: (i) retórica; (ii) políticas de ação afirmativa ou de igualdade de

\footnotetext{
${ }^{59}$ A proposição da criação de cotas para as direções internas surgiu no seio dos partidos políticos de esquerda, não sem, entretanto, encontrar resistência, inclusive das próprias mulheres, como se depreende do discurso da Deputada Marta Suplicy (PT/SP) proferido em agosto de 1995: "Lembro-me de que, quando isso [cotas de $30 \%$ nos cargos de direção do PT] foi votado, minha posição era de muita dúvida, uma dúvida que ia ao encontro de muitas mulheres, no sentido de se sentirem inferiorizadas. Por que temos que ter uma situação de privilégio? Por que ter uma cota? Será que não conseguimos chegar pela nossa competência, com as nossas próprias pernas? Isso, enfim, foi aprovado pelo PT, mas com muita dificuldade, porque muitas vezes as mulheres não querem, porque não têm condições de infraestrutura para, por exemplo, morar em Belém do Pará e vir para uma reunião da executiva em São Paulo. Com quem ficam os filhos?" (Marta Suplicy (PT/SP). Discurso. Diário do Congresso Nacional, Brasília, 04 ago. 1995. Seção I, p. 15855-15856.)

${ }^{60}$ LOVENDUSKI, Joni. Sex, Gender and British Politics. In: NORRIS, Pippa, e LOVENDUSKI, Joni. Gender and Party Politics. Londres: Sage, 1993.
} 
oportunidades; e (ii) políticas de discriminação positiva ${ }^{61}$. Essas estratégias não podem ser vistas como rígidas ou contrapostas entre si, havendo frequentemente interseções entre ações definidas para uma ou outra estratégia, sobretudo em se tratando de ações e discriminações positivas.

A estratégia da retórica implica a aceitação das questões das mulheres em plataformas de campanhas, com seu reconhecimento e assunção em discursos, sem, entretanto, existirem políticas efetivas sendo implementadas. Nas palavras do Secretário-Geral do Instituto Internacional para a Democracia e Assistência Eleitoral (IDEA), Vidar Helgesen: “Os partidos políticos são muito bons em fazer declarações sobre igualdade de gênero - mas eles, infelizmente, permanecem precários na identificação, seleção e nomeação de candidatas mulheres a posições de liderança." ${ }^{62}$. A estratégia da retórica pode ser mais ou menos concretizada a depender do compromisso de quem detém o poder no interior dos partidos, ressalvando-se que, nesse sentido, eventuais conquistas em direção a paridade de gênero possuem caráter de precariedade.

As estratégias de políticas de ação afirmativa ou de igualdade de oportunidades, por outro lado, visam promover ações que viabilizem que mulheres possam perseguir carreiras políticas nas mesmas condições que os homens. Exemplos ordinários incluem programas de treinamento nas habilidades de comunicação, de constituição de redes e de realização de campanhas, seminários, metas de inclusão a serem alcançadas pelo partido, ou ainda, adoção de políticas institucionais de apoio, como a provisão de creches e de instalações para cuidados com crianças. ${ }^{63}$ Destaca-se que as estratégias de igualdade de oportunidades podem ser neutras em relação ao gênero, podendo

\footnotetext{
61 ARAÚJO, Clara. Partidos políticos e gênero: mediações nas rotas de ingresso das mulheres na representação política. Revista de Sociologia e Política, núm. 24, jun; 2005, pp. 193-215. Universidade Federal do Paraná, Curitiba, Brasil.

${ }^{62}$ HELGESEN, Vidar. Discurso proferido em 06 de março de 2012, em Nova York, na Comissão das Nações Unidas para a condição feminina. Texto traduzido pela autora.

63 ARAÚJO, Clara. Partidos políticos e gênero: mediações nas rotas de ingresso das mulheres na representação política. Revista de Sociologia e Política, núm. 24, jun;, 2005, pp. 193-215. Universidade Federal do Paraná, Curitiba, Brasil.
} 
ser oferecidas tanto para candidatos homens quanto mulheres, entendendo-se que, na prática, mesmo que oferecidas a todos os candidatos, tais medidas tendem a beneficiar primariamente as mulheres ${ }^{64}$. A adoção de políticas de ação afirmativa para promoção de oportunidades iguais é valiosa a longo prazo, especialmente quando combinada com outras estratégias. Porém, por si só, na maioria das vezes, causam pouco impacto na elevação da representação feminina.

Por fim, as estratégias de discriminação positiva são explicitamente elaboradas para beneficiar mulheres durante um determinado período de tempo até que a paridade de gênero seja atingida nos órgãos legislativos e eletivos ${ }^{65}$. Pensadas como medidas temporárias, a adoção de tais estratégias implica uma intervenção mais incisiva, incluindo a adoção de sistemas de cotas para as instâncias decisórias dos partidos e para a representação pública do partido, conforme será abordado no Capítulo III. As ações de discriminação positiva tornaram-se crescentemente populares a partir da década de 1990, passando a ser a estratégia adotada por excelência. Entretanto, o uso de tais políticas permanece um tema controverso.

Destarte, os estudos empíricos apontam para uma relação entre o perfil ideológico do partido e o tipo de estratégia mais adotada, verificando-se que partidos de esquerda e partidos alternativos, como os partidos verdes, em conformidade com suas concepções acerca das formas de exclusão social e política que atingem certos segmentos sociais, são mais receptivos à adoção da estratégia de discriminação positiva, inclusive com a adoção de cotas

\footnotetext{
${ }^{64}$ NORRIS, Pippa. Recrutamento Político. In: CROTTY, W. \& KATZ, R. S. (eds) Handbook of Party Politics. Londres: Sage, 2006. Tradução de BOLOGNESI, Bruno.

${ }^{65}$ Convenção Sobre a Eliminação de Todas as Formas de Discriminação Contra a Mulher (1979) "Artigo $4^{\circ}$ - A adoção pelos Estados-partes de medidas especiais de caráter temporário destinadas a acelerar a igualdade de fato entre o homem e a mulher não se considerará discriminação na forma definida nesta Convenção, mas de nenhuma maneira implicará, como consequência, a manutenção de normas desiguais ou separadas; essas medidas cessarão quando os objetivos de igualdade de oportunidade e tratamento houverem sido alcançados." (grifo nosso)
} 
voluntárias $^{66}$. De outro lado, partidos mais conservadores e de ideologia mais identificada como de direita, tendem a adotar estratégias mais voltadas para a retórica, reconhecendo que existe necessidade de incorporação de mais mulheres no corpo político do país, desde que a competição eleitoral seja orientada pelo princípio da não-intervenção e não-regulação do processo de recrutamento, em uma visão similar a de um "livre mercado", em que o cenário da disputa eleitoral se equilibraria pela própria competição ${ }^{67}$.

Muito do debate na literatura procura determinar se os partidos políticos têm sido ativos ao democratizar o processo de recrutamento eleitoral. A fim de que os riscos eleitorais sejam minimizados e o partido consiga manter o poder já conquistado, os selecionadores e dirigentes partidários levam em consideração quem já está comprovadamente testado eleitoralmente ou quem tem potencial para entrar na disputa. A elite política, aqueles que já foram eleitos anteriormente e, portanto, já foi testada eleitoralmente, tem certas características típicas, como ser masculina, pertencer a certas profissões e a certos grupos étnicos ou sociais, de modo que vagas no processo de recrutamento e seleção são destinadas a candidatos que buscam a reeleição, fator comprovadamente desfavorável a mulheres ${ }^{68}$. Assim, sem formas de

\footnotetext{
${ }^{66}$ LOVENDUSKI, Joni. Sex, Gender and British Politics. In: LOVENDUSKI, Joni e NORRIS, Pippa. Women and Politics. Oxford: Oxford Univerisity. 1996. apud ARAÚJO, Clara. Partidos políticos e gênero: mediações nas rotas de ingresso das mulheres na representação política. Revista de Sociologia e Política, núm. 24, jun; 2005, pp. 193-215. Universidade Federal do Paraná, Curitiba, Brasil.

${ }^{67}$ NORRIS, Pippa, e LOVENDUSKI, Joni. Gender and Party Politics. Londres: Sage, 1993.

${ }^{68}$ Segundo relatório de 2014 da Secretaria de Políticas para as Mulheres ("As Mulheres nas Eleições de 2014"), o percentual de reeleição total da Câmara dos Deputados nas eleições de 2006 foi de 54\% e, entre as mulheres, esse percentual foi de 39,5\%. Em 2014, 391 deputados federais eleitos em 2010 tentaram a reeleição, dos quais 290 conseguiram, resultando em um percentual de reeleição de 74,17\%, enquanto que entre as mulheres, o percentual foi de $55 \%$, o que indica que as mulheres são discriminadas tanto nos partidos quanto no Parlamento, reproduzindo-se a composição excludente e elitista do bojo dos partidos políticos para o Parlamento e vice versa. (os dados sobre as eleições de 2014 estão disponíveis em: http://eleicoes.uol.com.br/2014/noticias/2014/10/06/so-14-dos-deputadosque-tentaram-novo-mandato-nao-sao-reeleitos-na-camara.htm, acesso em 23 de maio de 2015. O percentual de reeleição de deputadas mulheres foi calculado com base na lista de deputadas eleitas em 2010 e em 2014 disponível no site da Câmara dos Deputados e a lista de candidatos às eleições de 2014, acessível no sistema DivulgaCand2014 do TSE)
} 
intervenção externa, as alterações nos padrões de ingresso na elite política, com o acesso a representatividade no Congresso Nacional, tende a ocorrer em um ritmo inercial. Desse modo, a adoção de estratégias para a promoção de igualdade, como políticas de igualdade de oportunidades para mulheres e homens e políticas de discriminação positiva, como cotas de candidaturas ou de assentos administrativos ou legislativos, constituem medidas externas que quebrariam essa tendência.

Entretanto, conforme verificado anteriormente, as variáveis do sistema eleitoral e os contextos políticos de cada país afetam o modo como as mulheres se inserem na vida política nacional, de forma que a mera adoção de políticas de discriminação positiva, ainda que por imposição legal, pode não ser suficiente para causar um impacto na obtenção de paridade de gênero no âmbito representativo. Em países como o Brasil, em que o sistema eleitoral permanece estabelecendo listas abertas para os pleitos proporcionais, a existência de uma cota para o preenchimento de tal lista diz muito pouco sobre os compromissos dos partidos com a igualdade de gênero, criando-se um ambiente em que o importante não é tanto a obtenção de uma vaga para concorrer, mas as condições em que se está concorrendo, em especial o capital político e financeiro de que se dispõe para fazê-lo. 


\section{CAPÍTULO III - COTAS ELEITORAIS DE GÊNERO - SUAS MODALIDADES E EXPERIÊNCIAS NO CAMPO DA REPRESENTAÇÃO POLÍTICA}

As cotas eleitorais de gênero como medida de discriminação positiva surgiram em uma conjuntura de busca pela "democracia paritária", termo consolidado na Declaração de Atenas de 1992 e que serviu de marco para a reivindicação por maior participação feminina no corpo legislativo, inicialmente na Europa, e mais tarde, em outras partes do mundo. O conceito emergiu como uma resposta ao sistema democrático representativo e a seu conceito de cidadania construído, em sua origem, em nome de uma universalidade, que assumia o masculino como padrão e referência, causando, consequentemente, a exclusão política histórica das mulheres dos espaços de poder $^{69}$. As cotas passaram a apresentar-se como o meio mais eficaz para alcançar mudanças reais na busca pela paridade de gênero, lançando-se como uma proposta que visava garantir, em um primeiro momento, a representação descritiva $^{70}$ do grupo feminino nos parlamentos nacionais. Em um contexto em que ainda se atribui ao gênero feminino características de passividade e de exclusão da esfera pública, as cotas pretendem concretizar direitos de cidadania ativa que, ainda que formalmente reconhecidos, na prática, as mulheres não os conseguem exercer em condições de igualdade com os homens ${ }^{71}$.

\footnotetext{
${ }^{69}$ CABANILLAS, Beatriz Llanos. A modo de introducción: caminos recorridos por la paridad en el mundo. In: La apuesta por la paridad: democratizando el sistema político en América Latina. Los casos de Ecuador, Bolivia y Costa Rica. Peru: IDEA Internacional/ CIM Comissão Interamericana de Mulheres, 2013. p. 17-46.

${ }^{70}$ No presente trabalho "representação descritiva" significa a representação numérica, contraposta ao conceito de "representação substantiva", a qual remete-se ao conteúdo ou à natureza dessa representação.

${ }^{71}$ CABANILLAS, Beatriz Llanos. A modo de introducción: caminos recorridos por la paridad en el mundo. In: La apuesta por la paridad: democratizando el sistema político en América Latina. Los casos de Ecuador, Bolivia y Costa Rica. Peru: IDEA Internacional/ CIM Comissão Interamericana de Mulheres, 2013. p. 17-46.
} 
Do ponto de vista teórico, as propostas de cotas tiveram como importante embasamento a chamada "Teoria da Massa Crítica", que, aplicada à questão de paridade de gêneros na representação política, determina que a partir da presença de uma quantidade mínima de mulheres no parlamento, verificar-se-ia a formação de um polo de interesse que permitiria a atuação de mulheres como um grupo, ainda que minoritário, o que poderia impulsionar uma grande diferença nas deliberações e votações parlamentares ${ }^{72}$. A referida teoria associa a representação descritiva com uma consequente representação substantiva, presumindo que existe uma relação entre presença e ação parlamentar. Trata-se de uma política de presença, em que não apenas o que é representado, mas, sobretudo, quem representa, assumem centralidade quando se pensa o exercício e o acesso à representação política ${ }^{73}$. Todavia, na prática, a luta pelo aumento da presença feminina no âmbito político, não significa defender que necessariamente mulheres irão representar os interesses das mulheres, ou que não existam homens que defendam tais interesses. O que se verifica é que, com a ampliação do ingresso de mulheres na política, há indícios de que sua presença nas instâncias deliberativas superiores contribui para alargar a agenda política das mesmas ${ }^{74}$.

Com a criação de cotas eleitorais de gênero ao redor do mundo, o patamar geral em que se considera que se atinge uma presença mínima de mulheres no parlamento, para que estas efetivamente façam diferença, ficou estabelecido em torno de $30 \%^{75}$. Segundo dados do IPU $^{76}$, hoje em dia,

\footnotetext{
${ }^{72}$ DAHLERUP, Drude. From a Small to a Large Minority: Women in Scandinavian Politics. In: Scandinavian Political Studies, 11, p. 275-298, 1998 apud ARAÚJO, Clara. Cotas e financiamento de campanha. In: Cadernos Adenauer XIV, nº 3. São Paulo: Fundação Konrad Adenauer 2013. P. 11-30

${ }^{73}$ ARAÚJO, Clara. As cotas por sexo para a competição legislativa: o caso brasileiro em comparação com experiências internacionais. In Revista Dados, v. 44, n. 1. Rio de Janeiro: 2001

${ }^{74}$ Isso não implica defender que mais mulheres mudam o parlamento pelo simples fato de serem mulheres e possuírem qualidades diferenciadas por sexo que tornariam uma democracia "melhor".

${ }^{75}$ Resolução do Conselho Econômico e Social das Nações Unidas estabeleceu, em 1990, a meta de alcançar 30\% de mulheres em posições de tomada de decisões, em todos os níveis, até 1995, e 50\% até 2000.

${ }^{76}$ Dados coletados até o mês de maio, disponíveis em "http://www.ipu.org/wmnelarc/classif010515.htm" acesso em 28/05/2015.
} 
aproximadamente 43 países alcançaram a "massa crítica" de 30\% de mulheres nas câmaras baixas ou únicas de seus parlamentos, dos quais 37 adotam algum tipo de política de cota, conforme ilustrado na Figura $4^{77}$.

Figura 4

Adoção de cota eleitoral de gênero em países com alto nível de representação política de mulheres em seus parlamentos nacionais

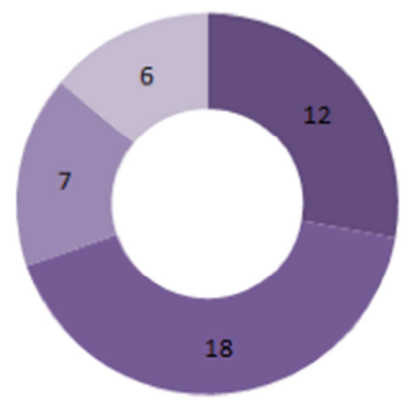

- Cotas Partidárias Voluntárias

- Cotas Legais Sobre o Processo Eleitoral

- Cotas Legais de Reserva de Assento Parlamentar

- Sem Cotas

Fonte: Dados disponibilizados pelo Inter-Parliamentary Union (IPU) até maio de 2015.

As cotas eleitorais de gênero são um mecanismo que visa garantir uma quantidade mínima de mulheres no parlamento eleito, por meio da estipulação de um número ou um percentual de mulheres a serem incluídas em determinada lista de candidatos ou de assentos parlamentares que devem ser reservados para as mesmas em uma legislatura ${ }^{78}$. Tais cotas usualmente recaem sobre a atuação dos partidos políticos, dada a compreensão de seu papel como canal de acesso a representação política, mitigando o ônus das candidatas de “correr atrás do prejuízo" para conseguir entrar de forma mais equitativa nos órgãos de tomada de decisão, posto que as ações de discriminação positiva alteram o balanço de incentivos para os selecionadores partidários. Embora constate-se que as medidas de discriminação positiva, atualmente, representam o meio mais eficiente para acelerar a entrada feminina nos corpos de representação política, é importante ressaltar que as cotas eleitorais de gênero não eliminam as barreiras estruturais, institucionais e/ou sociais que as

\footnotetext{
${ }^{77}$ Para os propósitos de elaboração do gráfico da Figura 4, cada país foi categorizado em apenas um grupo. Nos casos em que o país apresentava cotas legais em suas duas modalidades, deu-se preferência para representá-lo no campo de reserva de assento. No mesmo sentido, quando o país possuía cotas voluntárias e cotas legais, ele foi categorizado no campo das cotas legais.

${ }^{78}$ NORRIS, Pippa. Recrutamento Político. In: CROTTY, W. \& KATZ, R. S. (eds) Handbook of Party Politics. Londres: Sage, 2006. Tradução de BOLOGNESI, Bruno.
} 
mulheres podem encontrar na esfera política, permanecendo a necessidade de implementação de outras medidas que visem alcançar a paridade de oportunidades entre os gêneros ${ }^{79}$.

Existem duas modalidades principais de cotas eleitorais de gênero: as impostas pela legislação e as adotadas por iniciativa voluntária dos partidos políticos. As cotas legais recaem igualmente sobre todos os partidos e são fixadas por disposições constitucionais ou por legislações eleitorais especiais. Elas subdividem-se em dois grupos, as que incidem sobre o processo eleitoral, isto é, sobre as listas de candidatos apresentadas pelos partidos, e as que se aplicam diretamente ao parlamento, por via de reserva de assentos. Já as cotas voluntárias são adotadas por partidos políticos específicos, sendo estipuladas em seus estatutos ou normas internas, e recaem tão somente sobre suas próprias listas de candidatos.

Segundo dados do Banco de Dados de Cotas para Mulheres ${ }^{80}$, disponíveis na Tabela A do Anexo I, até maio de 2015, aproximadamente 112 países e territórios adotavam algum tipo de cota de gênero para o parlamento nacional, dos quais 77 utilizavam algum sistema de cotas legais (alguns combinando cotas sobre listas e de reserva de assento) e 53 possuíam ao menos um partido político que adotava algum tipo de cota voluntária para as eleições nacionais para a Câmara Baixa ou Única. Conforme abordado nos capítulos anteriores, diversos fatores influenciam as chances de êxito eleitoral de mulheres. Assim, embora verifique-se um alto número de países que adota algum sistema de discriminação positiva, os resultados das políticas de cotas variam muito, podendo ser menos ou mais bem-sucedidos ${ }^{81}$. A implementação eficaz de cotas eleitorais de gênero depende de múltiplos fatores, incluindo o

\footnotetext{
79 IDEA, IPU, Stockholm University. Atlas of Electoral Gender Quotas, 2013. (Acessível em: http://www.idea.int/publications/atlas-of-electoral-gender-quotas/)

${ }^{80}$ O Banco de Dados de Cotas para Mulheres é organizado e mantido por IDEA, IPU e Universidade de Estocolmo, disponível em http://www.quotaproject.org/ (acesso em 23 de maio de 2015).

81 Conforme constatado anteriormente, apenas 37 países que adotam alguma política de cota alcançaram a meta de $30 \%$ de representação parlamentar de mulheres.
} 
modo como os mecanismos legais são colocados em prática, a proporção definida pela cota, as regras para listas partidárias e as penalidades associadas ao descumprimento da $1 \mathrm{ei}^{82}$, nesse sentido, para obter-se resultados mais eficientes e significativos, cada política de cota deve ser pensada e engenhada para as especificidades de cada país.

\subsection{Cotas Legais Sobre o Processo Eleitoral}

As cotas legais de gênero que recaem sobre o processo eleitoral podem ser constituídas constitucionalmente (normalmente por meio do princípio da paridade) ou por legislação eleitoral especial. Usualmente, elas recaem sobre as Câmaras Baixas ou Únicas dos países, especificando que cada partido deve incluir uma proporção mínima de mulheres (ou do gênero sub-representado) em suas listas partidárias de candidatos ${ }^{83}$. Medidas de discriminação positiva cujas origens são o poder estatal, permitem que o Estado estabeleça sanções para o seu descumprimento e/ou incentivos financeiros relacionados ao fundo partidário, viabilizando a criação de um sistema de estímulo para que os partidos políticos promovam a igualdade de gênero. Ao impor uma política de cotas sobre o processo eleitoral, o Estado adquire o poder de desenhar as cotas de forma que sua aplicabilidade se torne mais eficiente e não se restrinja a uma mera formalidade legal.

Desse modo, o detalhamento da disposição legal que cria a ação de discriminação positiva torna-se imprescindível para garantir sua eficácia. Algumas leis são elaboradas mais como aberturas simbólicas do que como regulações de facto, uma vez que não obrigam os partidos a posicionarem as candidatas mulheres em suas listas com as mesmas condições de competição eleitoral do que os homens. A imposição de uma cota por meio legal não

\footnotetext{
${ }^{82}$ NORRIS, Pippa. Recrutamento Político. In: CROTTY, W. \& KATZ, R. S. (eds) Handbook of Party Politics. Londres: Sage, 2006. Tradução de BOLOGNESI, Bruno.

${ }^{83}$ NORRIS, Pippa. Recrutamento Político. In: CROTTY, W. \& KATZ, R. S. (eds) Handbook of Party Politics. Londres: Sage, 2006. Tradução de BOLOGNESI, Bruno.
} 
significa que a mesma será cumprida, ou que, ainda que formalmente obedecida, exista um comprometimento material com sua ideologia de igualdade de gênero por parte dos partidos.

Atualmente, 54 países adotam cotas legais sobre seus processos eleitorais para as Câmaras Baixas ou Únicas de seus parlamentos ${ }^{84}$, expandindo-se o número para 60 quando se consideram os países que também adotam esse tipo de cota para a Câmara Alta e/ou para o nível subnacional, conforme ilustrado na Figura $5^{85}$.

Figura 5

Países e territórios que adotam cotas legais sobre o processo eleitoral

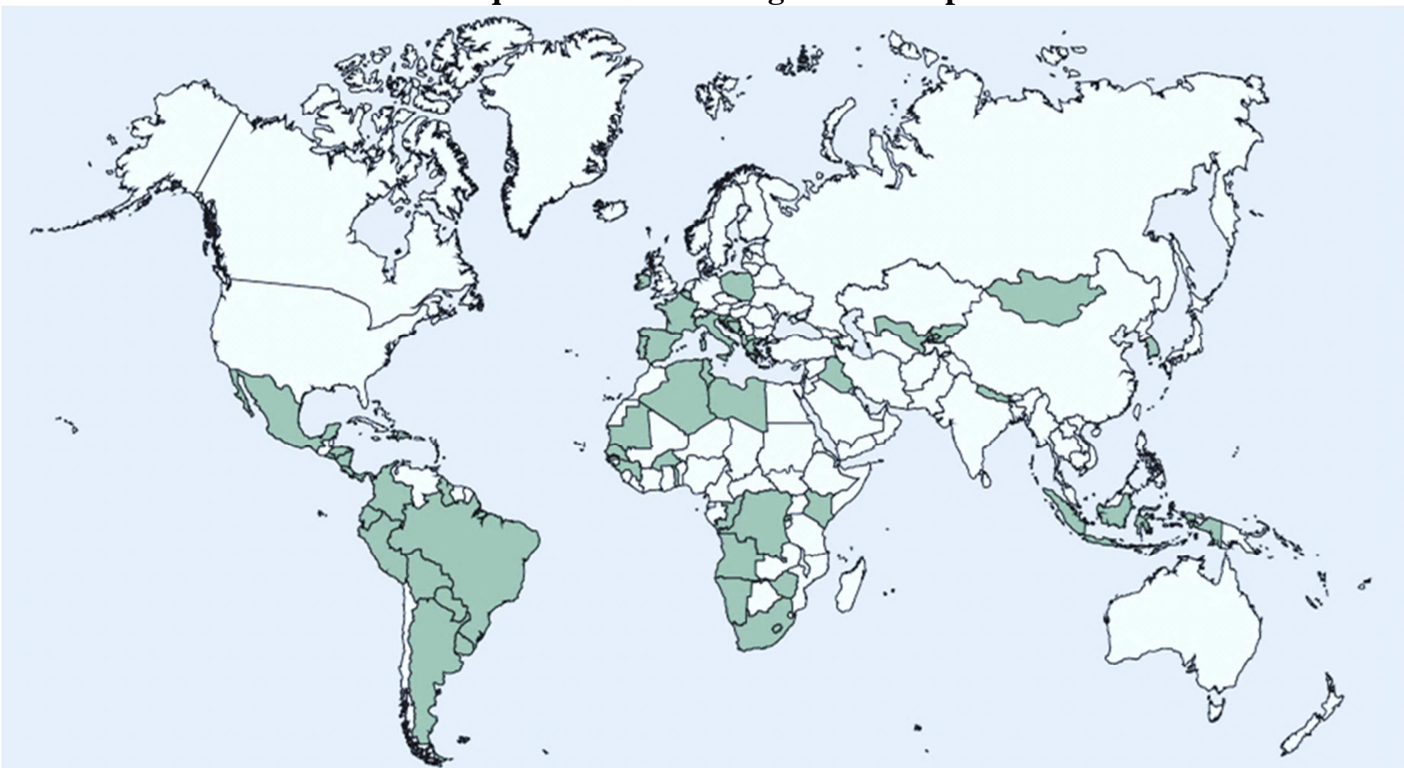

Américas: Argentina, Bolívia, Brasil, Colômbia, Costa Rica, El Salvador, Equador, Guiana, Honduras, México, Nicarágua, Panamá, Paraguai, Peru, República Dominicana e Uruguai. Europa: Albânia, Armênia, Bélgica, Bósnia e Herzegovina, Eslovênia, Espanha, França, Grécia, Irlanda, Itália, Kosovo, Macedônia, Montenegro, Polônia, Portugal e Sérvia. Ásia e Oceania: Coréia do Sul, Indonésia, Mongólia, Nepal, Quirguistão, Timor Leste, Uzbequistão. África e Oriente Médio: África do Sul, Angola, Argélia, Brazzaville (República do Congo), Burquina Faso, Cabo Verde, Guiné, Ilhas Maurício, Iraque, Lesoto, Líbia, Mauritânia, Quênia, República Democrática do Congo, Ruanda, Senegal, Namíbia, Palestina, Togo, Tunísia e Zimbábue. Fonte: Banco de Dados de Cotas para Mulheres, 2013.

O simples aumento quantitativo de candidatas não gera o necessário resultado de aumento de parlamentares eleitas, sendo fundamental que a lei disponha de mecanismos que (i) estabeleça incentivos ou sanções para o

\footnotetext{
${ }_{85}^{84}$ Dados retirados do Banco de Dados de Cotas para Mulheres em maio de 2015.

${ }^{85}$ IDEA, IPU, Stockholm University. Atlas of Electoral Gender Quotas, 2013. (Acessível em: http://www.idea.int/publications/atlas-of-electoral-gender-quotas/)
} 
cumprimento ou descumprimento das disposições legais, de forma suficiente para afetar a avaliação dos selecionadores partidários na sua análise de custobenefício de adimplência; e (ii) garanta as condições de exigibilidade das candidatas por meio da criação de critérios de posicionamentos e classificações para as listas partidárias.

A estipulação de sanções significativas e sua efetiva imposição para os casos de descumprimento da lei de cotas é crucial para garantir a aderência dos partidos políticos e sua conformação às determinações legais. As principais modalidades de sanções encontradas na experiência internacional referem-se à (i) rejeição da lista de candidatos antes do pleito eleitoral; e (ii) aplicação de multas/penalidades de cunho financeiro, com a possibilidade de aplicação reversa da "sanção", concedendo-se incentivos aos partidos que cumprem a $1 \mathrm{i}^{86}$

A rejeição de uma lista de candidatos pode ser total ou parcial e normalmente é precedida de uma notificação ao partido político de não conformidade (non-compliance) com as regras principais relativas à aplicação das $\operatorname{cotas}^{87}$. Embora possua alto grau de efetividade ${ }^{88}$ dado o risco apresentado ao partido de sua exclusão do pleito eleitoral, o método da rejeição é criticado, pois a inserção de candidatas mulheres "de última hora" apenas para garantir o

\footnotetext{
${ }^{86} \mathrm{O}$ caso chileno é um exemplo de incentivo financeiro diferenciado para o cumprimento da lei, pois estabelece que, em suas próximas eleições nacionais, previstas para 2017, os partidos serão recompensados por cada voto que as candidatas mulheres receberem, independentemente de elas serem eleitas ou não. Adicionalmente, os partidos receberão um acréscimo de investimento estatal para cada candidata que eles conseguirem de fato eleger. (Fonte: http://www.idea.int/gender/women-in-politicsachieving-key-milestones.cfm, acesso em 17 de maio de 2015).

${ }^{87} \mathrm{Na}$ Espanha, por exemplo, os partidos possuem o prazo de 3 dias contados do recebimento da notificação para adequarem suas listas às regras legais, sujeitos a rejeição e impedimento de participação naquele determinado pleito eleitoral.

${ }^{88}$ Países que adotam esse tipo de sanção e em que as autoridades responsáveis pela fiscalização do processo eleitoral de fato aplicam as penalidades estipuladas, como a Bélgica e a Costa Rica (após decisão de seu tribunal superior eleitoral, em 1999), atingiram e mantiveram percentuais elevados de mulheres em seus parlamentos (em maio de 2015, Bélgica e Costa Rica possuíam respectivamente 39\% e 33\% de mulheres em suas Câmaras Baixas/Únicas). (IPU, 2015)
} 
cumprimento da lei não contribui para a alteração do processo sistemático de exclusão de mulheres dos procedimentos de recrutamento eleitoral ${ }^{89}$.

As sanções de cunho financeiro normalmente são concretizadas por meio da estipulação de aplicação, nos casos de descumprimento das determinações legais, de uma multa de valor determinado aos partidos, ou de uma redução no financiamento público a ser recebido pelo partido. Em comparação com a possibilidade de rejeição da lista de candidatos e exclusão do pleito eleitoral, as sanções financeiras são menos efetivas em sua função de punir o não-cumprimento de cotas. Os partidos, ao avaliarem as penalidades e os benefícios potenciais no caso de cumprirem ou não a lei, podem considerar politicamente preferível arcar com as multas impostas e garantir sua engenharia política a sacrificarem suas metas de eleição e suas estratégias de indicação ${ }^{90}$, de modo que podem optar por seguir com a indicação tradicional de candidatos homens ${ }^{91}$, em detrimento do mínimo legal de mulheres e suportar o custo financeiro de tal decisão ${ }^{92}$. Por vezes, a escolha por desobedecer a lei se dá pelo baixo valor da multa ou, nos casos em que a penalidade (ou incentivo) recai sobre o financiamento público, pelo alto poder de atração de investimentos privados do partido, fazendo com que o mesmo não dependa das verbas estatais ${ }^{93}$.

\footnotetext{
${ }^{89}$ IDEA, IPU, Stockholm University. Atlas of Electoral Gender Quotas, 2013. (Acessível em: http://www.idea.int/publications/atlas-of-electoral-gender-quotas/)

${ }^{90}$ ARAÚJO, Clara. Cotas e financiamento de campanha. In: Cadernos Adenauer XIV, $\mathrm{n}^{\circ}$ 3. São Paulo: Fundação Konrad Adenauer 2013. P. 11-30

${ }^{91}$ NORRIS, Pippa. Recrutamento Político. In: CROTTY, W. \& KATZ, R. S. (eds) Handbook of Party Politics. Londres: Sage, 2006. Tradução de BOLOGNESI, Bruno.

${ }^{92}$ Em 1999, a França estabeleceu, por meio de emenda constitucional, o princípio de paridade para seu parlamento. Tal disposição constitucional foi regulamentada pela lei de paridade de gênero, aprovada em 2000, que especificava que para as eleições para a Assembleia Nacional, a divisão de parlamentares por gênero não poderia ultrapassar a relação de $48 \%$ e $52 \%$, sob pena de corte do financiamento público ao partido. Nas eleições de 2002, os maiores partidos decidiram favorecer candidatos à reeleição e ignoraram a punição financeira por suas listas partidárias desequilibradas, de modo que a proporção de mulheres eleitas cresceu somente $1,4 \%$, muito aquém do resultado esperado com base nas eleições municipais que apresentaram crescimento de $22 \%$.

93 IDEA, IPU, Stockholm University. Atlas of Electoral Gender Quotas, 2013. (Acessível em: http://www.idea.int/publications/atlas-of-electoral-gender-quotas/)
} 
Paralelamente à necessidade de estabelecer mecanismos que certifiquem o cumprimento da lei e a presença de um mínimo de mulheres na competição de determinado pleito eleitoral, é preciso criar condições para que tais candidatas concorram aos cargos em condições de viabilidade de êxito. Desse modo, as ações de discriminação positiva devem definir critérios formais de posicionamento dos gêneros dentro das listas partidárias, criando dessa forma um ordenamento ranqueado entre os candidatos que visa impedir que as cotas sejam meramente simbólicas. As regras para posicionamento recaem sobre as listas partidárias, de modo que somente têm aplicabilidade nos Sistemas Proporcionais que trabalham com listas fechadas, estabelecendo-se critérios como, por exemplo, o de alternância ${ }^{94}$, de presença mínima obrigatória de uma mulher a cada certa quantidade de candidatos homens ou de determinação de que os dois candidatos no topo da lista sejam de gêneros diferentes. A simples aplicação da cota percentual sem a estipulação de regras de ordenamento não possui o condão de, por si só, garantir um número mínimo de mulheres eleitas, posto que as mesmas podem ser posicionadas no fim das listas fechadas, ou, no caso de listas abertas, não receberem recursos de forma similar a candidatos homens de forma a permitir uma concorrência paritária.

\subsection{Cotas Legais de Reserva de Assento Parlamentar}

Por meio de legislação eleitoral específica, alguns países têm estipulado um número determinado de mulheres ou minorias étnicas que necessariamente irá compor determinado corpo legislativo, seja por meio de indicação, eleição indireta ou eleição direta. A política de reserva de assentos parlamentares é o tipo de cota menos utilizado no mundo, sendo frequentemente associado a um meio de aumentar a representação feminina em países "em desenvolvimento"

\footnotetext{
${ }^{94}$ Também chamado de "Lista Zebrada".
} 
que adotam Sistemas Majoritários, embora não se restrinja a eles ${ }^{95}$. Nesse sentido, as vagas reservadas têm ganhado popularidade nos países africanos e do sudeste asiático, especialmente naqueles com cultura muçulmana. Esse mecanismo garante um número mínimo de mulheres no parlamento eleito. Entretanto, determinar a eleição de mulheres não significa necessariamente conferir a elas um substantivo poder de decisão, principalmente quando as posições reservadas são ocupadas por indicação.

Figura 6

Países e territórios que adotam cotas legais de reserva de assento parlamentar

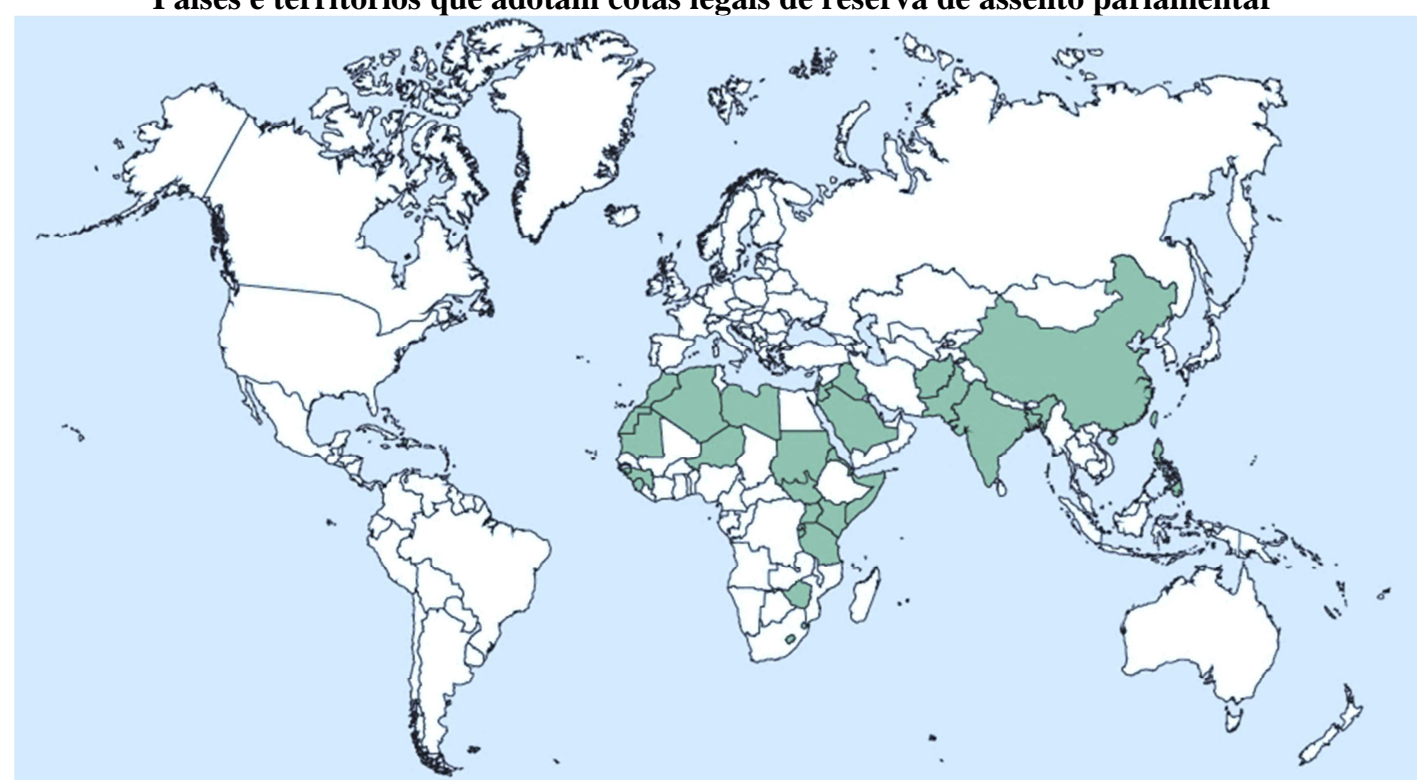

Américas: Haiti. Europa: Kosovo. Ásia e Oceania: Afeganistão, Bangladesh, China, Filipinas, Índia, Paquistão, Samoa, Taiwan, Timor Leste e Vanuatu. África e Oriente Médio: Arábia Saudita, Argélia, Burundi, Djibuti, Eritreia, Guiné, Iraque, Jordânia, Lesoto, Líbia, Marrocos, Mauritânia, Níger, Quênia, Palestina, Ruanda, Serra Leoa, Somália, Sudão, Sudão do Sul, Suazilândia, Tanzânia, Uganda e Zimbábue.

Fonte: Banco de Dados de Cotas para Mulheres, 2013.

Segundo o Banco de Dados de Cotas para Mulheres, e ilustrado na Figura 6, até 2013, 36 países ou territórios adotavam cotas legais de reserva de assentos parlamentares no nível nacional ou local, utilizando especialmente os métodos de criação de (i) um sistema de votação em separado para candidatas

\footnotetext{
${ }^{95}$ NORRIS, Pippa. Recrutamento Político. In: CROTTY, W. \& KATZ, R. S. (eds) Handbook of Party Politics. Londres: Sage, 2006. Tradução de BOLOGNESI, Bruno.
} 
mulheres, seja pela designação de distritos que somente podem eleger mulheres (como em Ruanda, em que as mulheres são eleitas em determinadas províncias por meio de colégios eleitorais específicos), seja pela estipulação de uma lista separada de candidatas mulheres para ocuparem as vagas reservadas (como no Marrocos e na Mauritânia); e (ii) um sistema de "melhor perdedor", em que os assentos reservados para mulheres seriam ocupados pelas candidatas que angariaram mais votos em seus distritos, quando comparadas a outras mulheres, mas que não foram suficientes para elegê-las (como na Jordânia) ${ }^{96}$. Alguns países, como Paquistão, Tanzânia e Zimbábue, também reservam vagas para mulheres em seus parlamentos, porém não exigem que elas sejam eleitas diretamente.

Considerando as experiências internacionais, as cotas devem ser pensadas e desenhadas em um sistema que garanta para as candidatas eleitas legitimidade conferida pelo processo democrático. Verifica-se que, onde as mulheres possuem uma base eleitoral, ou seja, nos locais em que não ocupam o cargo por indicação ou em razão de cadeiras alcançadas por seu partido, elas podem ser mais independentes da liderança partidária. Ao revés, quando indicadas pela liderança partidária, pelo Presidente, ou por algum outro órgão, as mulheres podem não ter acesso a qualquer responsabilidade real de tomada de decisão, de modo que suas indicações para ocupação do assento se tornem tão somente um poder de reforço do controle do parlamento pelo partido majoritário 97 .

\subsection{Cotas Partidárias Voluntárias}

As cotas voluntárias de gênero são definidas como regras partidárias internas, estipuladas por meio de disposições estatutárias ou normativas, que

\footnotetext{
96 IDEA, IPU, Stockholm University. Atlas of Electoral Gender Quotas, 2013. (Acessível em: http://www.idea.int/publications/atlas-of-electoral-gender-quotas/)

${ }^{97}$ NORRIS, Pippa. Recrutamento Político. In: CROTTY, W. \& KATZ, R. S. (eds) Handbook of Party Politics. Londres: Sage, 2006. Tradução de BOLOGNESI, Bruno.
} 
especificam que o partido deve incluir uma proporção mínima de mulheres como candidatas para cargos eletivos ${ }^{98}$. Criadas originalmente no seio de partidos de esquerda ou de viés alternativo, como os partidos verdes, as cotas voluntárias espalharam-se pelo continuum ideológico pelo "efeito-contágio" e foram responsáveis por avanços significativos na direção da paridade de gênero em diversos países, com diferentes níveis de desenvolvimento democrático. Conforme ilustrado na Figura 7, cerca de 37 países possuíam, em 2013, ao menos um partido que adotava voluntariamente uma cota de gênero.

Figura 7

Países e territórios que adotam cotas partidária voluntárias

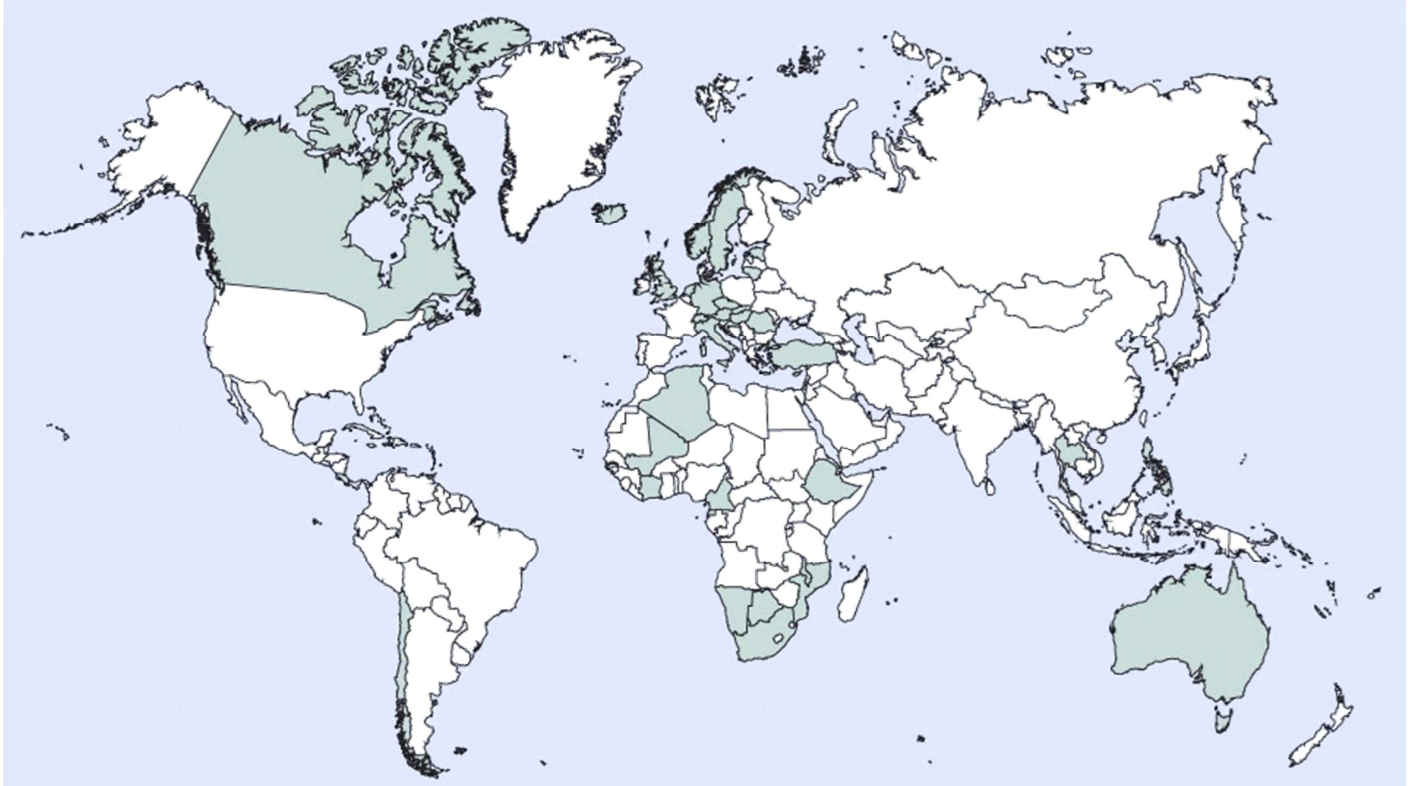

Américas: Canadá, Chile e Guatemala. Europa: Alemanha, Áustria, Croácia, Chipre, Eslováquia, Estônia, Holanda, Hungria, Islândia, Itália, Lituânia, Luxemburgo, Malta, Noruega, Reino Unido, República Checa, Romênia, Suécia, Suíça e Turquia. Ásia e Oceania: Austrália, Filipinas e Tailândia. África e Oriente Médio: África do Sul, Botsuana, Camarões, Costa do Marfim, Guiné Equatorial, Israel, Malaui, Mali, Moçambique e Namíbia.

Fonte: Banco de Dados de Cotas para Mulheres, 2013.

Em diversos países, a origem das cotas legais foi a adoção de cota voluntária por um ou mais partidos precursores, com a posterior imposição a

\footnotetext{
${ }^{98}$ NORRIS, Pippa. Recrutamento Político. In: CROTTY, W. \& KATZ, R. S. (eds) Handbook of Party Politics. Londres: Sage, 2006. Tradução de BOLOGNESI, Bruno.
} 
todo o sistema partidário a partir da edição de legislações especificas ${ }^{99}$. Assim como as cotas legais sobre o processo eleitoral, as variáveis em relação ao tipo de lista de candidatos também influenciam a eficácia das cotas voluntárias, de modo que as mesmas observações feitas na seção Cotas Legais Sobre o Processo Eleitoral são cabíveis ${ }^{100}$. Entretanto, ressalta-se que, a partir de sua autonomia orgânica, qualquer partido político pode estipular cotas voluntárias de gênero, não se restringindo necessariamente às que recaem sobre pleitos eleitorais, uma vez que as medidas de discriminação positiva também podem incidir sobre cargos de direção interna.

Porque dependem tão somente da iniciativa interna do partido político, e não do processo legislativo, cotas voluntárias também são mais simples e fáceis de serem adotadas. Uma das principais vantagens percebidas quanto à adoção de cotas voluntárias é a sua tendência a serem obedecidas e devidamente implementadas pelos partidos, em especial, quando o partido possui um alto nível de institucionalização. Ademais, ressalta-se que o impacto das cotas voluntárias depende muito do compromisso material dos partidos políticos com a igualdade de gênero, verificado por meio do posicionamento das mulheres no pleito eleitoral com condições de elegibilidade e da realização de financiamento adequado de suas campanhas eleitorais ${ }^{101}$.

A comparação entre os diferentes tipos de cotas, considerando-se suas interações com os sistemas políticos e eleitorais encontrados no mundo, sugere que é necessário cautela na expectativa de que a adoção de uma estratégia de ação de discriminação positiva produza automaticamente ou em curto prazo

\footnotetext{
${ }^{99}$ Exemplos de países em que cotas voluntárias antecederam a implementação de cotas legais são a Bélgica, Bósnia Herzegovina, Eslovênia e Espanha. Normalmente, a iniciativa legislativa para a instituição de cotas legais veio dos partidos que já adotava cotas voluntariamente. (Parlamento Europeu. Elecoral Gender Quota Systems and Their Implementation in Europe. 2008. p.30)

100 IDEA, IPU, Stockholm University. Atlas of Electoral Gender Quotas, 2013. (Acessível em: http://www.idea.int/publications/atlas-of-electoral-gender-quotas/)

${ }^{101}$ Dinheiro e campanha política são partes integrantes de campos associados com o processo eleitoral, como a realização de propaganda e presença na mídia. Estudo realizado sobre as eleições gerais de 2002 e 2006 constataram, por exemplo, que os candidatos vencedores gastaram em média, cinco vezes mais do que seus adversários.
} 
aumento nas taxas de representação política de mulheres no âmbito do Poder Legislativo. Portanto, a análise das cotas no Brasil deve buscar compreender o porquê de sua ineficácia como estratégia de acesso feminino à representação política. Como será exposto no Capítulo IV, a legislação que estabeleceu a Lei de Cotas no Brasil possui alguns itens que a tornam pouco eficaz. No mesmo sentido, a ausência de normas regulamentadoras permite a existência de brechas legais, que são utilizadas pelos partidos políticos para a manutenção do status quo, com o predomínio masculino na tomada de decisões internas partidárias e ocupação de cargos públicos, de modo que as estipulações legais da Lei de Cotas não foram capazes de alterar a dinâmica do processo eleitoral $^{102}$.

102 ARAÚJO, Clara. As cotas por sexo para a competição legislativa: o caso brasileiro em comparação com experiências internacionais. In Revista Dados, v. 44, n. 1. Rio de Janeiro:2001 (disponível em: http://dx.doi.org/10.1590/s0011-52582001000100006) 


\section{CAPÍTULO IV - COTAS ELEITORAIS DE GÊNERO NO BRASIL - ACESSO E INSERÇÃO DA MULHER NO CENÁRIO POLÍTICO BRASILEIRO}

A política, como um dos campos historicamente dominado pelos homens, está estruturada de forma a possibilitar a reprodução da hierarquia já institucionalizada em que os espaços de poder são reservados ao gênero masculino. Embora o mito da falta de interesse e da natural apatia feminina na política já tenha sido derrubado, o condicionamento cultural que o reproduz, na forma de estereótipos do tipo "política é coisa de homem" e em crenças que associam a esfera política à masculinidade, permanece forte, refletindo-se no déficit de gênero das instituições de poder ${ }^{103}$. No Brasil, a campanha eleitoral é marcada desde o princípio pelo baixo número de mulheres que se candidatam a um cargo político, o que reflete-se nos ainda mais baixos resultados eleitorais, especialmente nas eleições em nível federal ${ }^{104}$.

A política de cotas pretende corrigir a desigualdade de gênero que se manifesta entre o número de candidaturas de mulheres e de homens, alterando percepções e valores e ampliando os compromissos nacionais e partidários com a proposta, à medida que estabelece responsabilidades partidárias e intervenções institucionais concretas, visando, em última análise, superar o quadro de sub-representação política das mulheres ${ }^{105}$. O entendimento do resultado da política de cotas no Brasil passa pela compreensão das características da legislação que as instituiu, da interação desta com os sistemas político-eleitoral nacional em que se insere, e do comportamento

\footnotetext{
103 ARAÚJO, Clara. Partidos políticos e gênero: mediações nas rotas de ingresso das mulheres na representação política. Revista de Sociologia e Política, núm. 24, jun; 2005, pp. 193-215. Universidade Federal do Paraná, Curitiba, Brasil.

${ }^{104}$ Em janeiro de 2015, o Brasil ocupava o $117^{\circ}$ lugar no ranking de 189 países elaborado pela IPU e organizado por percentual de mulheres presentes nas Câmaras Baixas ou Únicas de seus parlamentos. (IPU and UN Women, "Women in Politics: 2015")

105 ARAÚJO, Clara. As cotas por sexo para a competição legislativa: o caso brasileiro em comparação com experiências internacionais. In Revista Dados, v. 44, n. 1. Rio de Janeiro: 2001
} 
partidário frente às regras de promoção de igualdade de gênero. Considerando os limites de eficácia das cotas, na forma como se apresentam na legislação atual, em face do sistema eleitoral vigente, evidencia-se a necessidade de adequação de um ou de outro para a obtenção de melhores resultados.

Neste capítulo, analisa-se a experiência brasileira na adoção de medidas de discriminação positiva no âmbito eleitoral, tecendo-se um breve panorama histórico até ser alcançado o conteúdo da última versão da Lei de Cotas. Em seguida, aborda-se a evolução dos resultados das eleições gerais para deputados federais no período em que as cotas foram implementadas. Por fim, expõe-se as possíveis razões para os resultados alcançados e quais mudanças poderiam ser ocasionadas com uma Reforma Política, destacando-se os projetos de lei atualmente em debate no Congresso Nacional.

\subsection{A Trajetória da Lei de Cotas - Alguns Antecedentes Históricos}

O Brasil se tornou um dos primeiros países da América Latina a reconhecer o direito ao voto feminino, fazendo-o em 1932 $2^{106}$, com a promulgação do Código Eleitoral (Decreto $n^{\circ}$ 21.076/1932), e sua posterior consolidação na Carta Constitucional de 1934, ano em que a primeira mulher, Carlota Pereira de Queirós, foi eleita para o Congresso Nacional. Não faltaram, entretanto, medidas restritivas quanto ao exercício da cidadania política feminina, variando de exigências específicas ao gênero - como comprovação de vínculos trabalhistas, da posse de propriedade ou autorização do marido ${ }^{107}$ a exigências genéricas, mas com efeitos significativos sobre as mulheres como a exigência de alfabetização, o que excluía parcela significativa de

\footnotetext{
${ }^{106} \mathrm{Em}$ ato isolado, o alistamento de mulheres foi reconhecido no estado do Rio Grande do Norte, em 1927. Como resultado, várias mulheres puderam exercer seu direito de voto, elegendo, em 1928, a primeira prefeita brasileira - Alzira Soriano.

${ }_{107}$ ALVES, Branca. Moreira. Ideologia e feminismo: a luta da mulher pelo voto no Brasil. Petrópolis: Vozes, 1980.
} 
mulheres que se somavam ao contingente de analfabetos do país ${ }^{108}$. A história política brasileira registrou, a partir de então, longos períodos de suspensão da democracia, como o Estado Novo (1937 a 1945) e o Regime Militar (19641985), o que não contribuiu para fazer progredir em ritmo mais acelerado a inserção da mulher na esfera política nacional. Tal fato pode ser comprovado por apenas 26 mulheres terem sido eleitas para a Assembleia Nacional Constituinte $^{109}$ nas eleições gerais de 1986, representando apenas 4,9\% das cadeiras ocupadas, enquanto as mulheres representavam $52 \%$ do eleitorado nacional e $54 \%$ da população brasileira ${ }^{110}$.

O debate sobre a participação política da mulher no Congresso Nacional até a década de 1990 foi tratado como uma questão de pouca relevância, estando presente apenas, quase que exclusivamente, nas comemorações do Dia Internacional da Mulher. A trajetória que conduziu à aprovação das cotas no Brasil não foi marcada por grandes debates ou polêmicas e não chegou a mobilizar setores mais amplos da sociedade, predominando, em geral, uma posição de questionamento acerca de sua natureza e viabilidade ${ }^{111}$. Somente em dezembro de 1993 é que foi proposto explicitamente uma política de ação de discriminação positiva visando o aumento da participação feminina no Poder Legislativo, por meio de um grupo de propostas de emendas ao Código Eleitoral (Lei n ${ }^{o} 4.737$ de 1965), de iniciativa do PSDB. Dentre as propostas, encontrava-se a de criação de cota de reserva de assentos parlamentares para

\footnotetext{
${ }^{108}$ Tal restrição, instituída pela Constituição de 1946, somente foi eliminada na Constituição de 1988, com a concessão do voto facultativo aos analfabetos.

${ }^{109}$ Foram eleitas 26 mulheres constituintes, mas somente 25 tomaram posse. (TABAK, Fanny. Mulheres Públicas: Participação Política e Poder. Rio de Janeiro: Letra Capital, 2002. P. 156)

${ }^{110}$ MIGUEL, Sônia Malheiros. A política de cotas por sexo: um estudo das primeiras experiências no Legislativo brasileiro. Brasília: CFEMEA, 2000. P.39

111 ARAÚJO, Clara. As cotas por sexo para a competição legislativa: o caso brasileiro em comparação com experiências internacionais. In Revista Dados, v. 44, n. 1. Rio de Janeiro:2001 (disponível em: http://dx.doi.org/10.1590/s0011-52582001000100006)
} 
que houvesse a presença obrigatória de mulheres nos Parlamentos, de todos os níveis de poder, em um percentual mínimo de $30 \%$ de suas composições ${ }^{112}$.

Em 1995, com a realização da IV Conferência Mundial sobre a Mulher em Beijing, foram apresentadas propostas de ações e definidos objetivos estratégicos para buscar a democracia paritária ${ }^{113}$. Embora o Brasil tenha assumido como objetivo nacional a adoção de medidas e políticas públicas para garantir à mulher igualdade de acesso e plena participação nas estruturas de poder e de tomada de decisão, com a proximidade das eleições municipais de 1996, a discussão sobre a adoção de cotas assumiu um caráter restritivo ao âmbito municipal. Nesse diapasão, por meio de projeto de lei de autoria da Senadora Junia Marise (PDT/MG), a proposta discutida no Congresso Nacional era a de que a cota mínima para mulheres fosse de $20 \%$, atrelando-a ao aumento do número de candidaturas máximo permitido por partido, que passaria a ser de $120 \%$ do número de lugares a preencher ${ }^{114}$. Tal aumento do percentual do número total de candidaturas decorreu de um acordo entre os partidos políticos e significou a diminuição do impacto das cotas, como é possível observar pelo discurso de Marta Suplicy (PT/SP), ao explicitar o seu voto e o do PT pela aprovação da emenda do Senado ${ }^{115}$, que consagrou-se no texto da Lei $n^{\circ} 9.100 / 1995$.

\footnotetext{
${ }^{112}$ MIGUEL, Sônia Malheiros. A política de cotas por sexo: um estudo das primeiras experiências no Legislativo brasileiro. Brasília: CFEMEA, 2000. P.41

${ }^{113}$ No mesmo ano, 52 parlamentares federais da América Latina estiveram reunidas na sede do Parlatino, em São Paulo, na VI Reunião Ampliada da Comissão Especial da Mulher do Parolamento Latino-Americano, em preparação para a Conferência em Beijing. Nesse contexto, o Brasil comprometeu-se a promover a democratização do sistema político brasileiro e a exigir dos partidos políticos um estímulo a participação feminina no comando partidário, no parlamento e em cargos públicos ou de eleição popular positiva, obrigando-os a garantir um financiamento adequado a assegurar a igualdade de oportunidades entre ambos sexos, passando assim, a incorporar a perspectiva de gênero nas políticas públicas (Periódico "Fêmea" CFEMEA - Centro Feminista de Estudos e Assessoria - Ano III n 31, Brasília - DF, Agosto/95.)

114 MIGUEL, Sônia Malheiros. A política de cotas por sexo: um estudo das primeiras experiências no Legislativo brasileiro. Brasília: CFEMEA, 2000. P.42

${ }^{115} \mathrm{O}$ texto aprovado na Câmara não alteraria o número de candidaturas de cada partido, mas colocaria $20 \%$ além do percentual total já destinado a cada partido reservado para as mulheres, não acarretando na diminuição do número de candidaturas de homens. A proposta do Senado levaria a um total de $24 \%$ das candidaturas reservadas às mulheres (20\% de $120 \%)$.
} 
"Acho que a proposta só passou porque nós, mulheres, não estávamos todas aqui para poder explicar aos nossos colegas Parlamentares a importância desses $20 \%$ estarem dentro do número normal de candidatos. Era essa a nossa ideia porque assim obrigaria os partidos a investirem nas candidaturas femininas. (...)

Entretanto, avaliamos que ainda assim, é melhor aumentar o número de candidaturas para $120 \%$ e ter as $20 \%$ do que manter o que foi aprovado na Câmara, porque aí realmente representa um degredo absoluto, um vexame para nós, mulheres, a condição proposta pela Câmara." (Deputada Marta Suplicy - PT/SP) ${ }^{116}$

As eleições municipais de 1996 apresentaram um percentual de candidatas próximo da cota mínima estabelecida, com o alcance de $18 \%$ do total de candidatos, e um crescimento no percentual de vereadoras eleitas, que passou, segundo dados do TSE, de 7,5\% em 1992, para 11,2\% em 1996. Dando continuidade ao debate, o Congresso Nacional voltou-se para as eleições gerais de 1998 e para a possibilidade de expansão das cotas para os âmbitos Estaduais e Federal. Nos discursos proferidos, encontram-se posições como a do Senador Ramez Tebet (PMDB/MS), que se pronunciou no sentido de que a "reserva de mercado" criada para estimular a participação feminina na vida pública brasileira foi acertada no âmbito municipal, mas que a vida pública é "decorrência de uma vocação natural", de modo que a expansão das cotas para as eleições estaduais e federais deveria ser estudada com cautela, pois muitos partidos lançaram, em 1996, candidatas mulheres apenas para cumprir a cota e "não se pode forçar a barra na vida pública" ${ }^{117}$. Manifestações desse teor, além de realçarem a oposição para incluir as mulheres nas esferas de poder e nos níveis mais altos do legislativo, expuseram o peso das concepções patriarcais, fundadas na legitimidade do poder masculino frente à emancipação feminina.

No final de 1997, quando foi votada a nova lei eleitoral, de $\mathrm{n}^{\circ} 9.504$ ("Lei de Eleições"), que estabeleceu regras permanentes para os futuros pleitos eleitorais, incluindo as eleições gerais de 1998, as cotas como reservas de

\footnotetext{
${ }^{116}$ Discurso. Diário do Congresso Nacional, Brasília, 28 set. 1995. Seção I, p. 23950- 23952.

${ }^{117}$ Discurso. Diário do Senado Federal, Brasília, 22 out. 1996. p. 17295.
} 
vagas em listas parlamentares foram incluídas como legislação permanente ${ }^{118}$, aplicadas às eleições proporcionais para a Câmara dos Deputados, Assembleias Legislativas, Câmara Distrital e Câmaras de Vereadores. A Lei de Eleições foi aprovada com o texto assegurando uma cota mínima, que deixou de ser restrita às mulheres, de $30 \%$ e máxima de $70 \%$ para cada gênero, com um artigo nas disposições transitórias que excepcionava esta proporção para $25 \%$ e $75 \%$ nas eleições de $1998^{119}$. A mesma lei alterava o número máximo de candidaturas em relação ao número de vagas pelo partido para até $150 \%$ do número de lugares a preencher ${ }^{120}$ e permanecia silente quanto a obrigatoriedade de cumprimento das cotas.

\subsection{A Legislação Atual e os Resultados Eleitorais}

A atual redação da Lei de Eleições foi dada pela minirreforma eleitoral ocorrida em 2009, com a promulgação de uma série de leis, dentre elas as Leis $\mathrm{n}^{\mathrm{o}} 5.498 / 2009$ e $12.034 / 2009^{121}$. A política de cotas foi mantida com os mesmos percentuais mínimos e máximos anteriores, com a diferença que, a partir da alteração da redação do Artigo $10, \S 3^{\circ}$, as cotas tornaram-se

\footnotetext{
${ }^{118}$ Embora opiniões individuais de congressistas ressaltam-se o receio da ampliação do âmbito de aplicação das cotas, entre os partidos políticos, não se explicitaram muitos conflitos quanto à aprovação da legislação. Representantes de partidos de esquerda, centro e direita apoiaram e até mesmo defenderam a proposta de ação de discriminação positiva, sem que fossem registrados questionamentos acerca de sua constitucionalidade. Conforme explicitou-se, a legislação não só ampliou o rol de candidatos, diminuindo a influência das cotas, como também não trouxe punições por seu descumprimento, de modo que sugere-se que, caso a redação da lei de cotas implicasse de imediato na alteração da engenharia política eleitoral, deslocando efetivamente os atores tradicionais em favor das mulheres, a situação não teria sido a mesma.

119 O parágrafo terceiro do artigo 10 desta Lei ficou assim redigido "Do número de vagas resultantes das regras previstas neste artigo, cada partido ou coligação deverá reservar o mínimo de trinta por cento e o máximo de setenta por cento para candidaturas de cada sexo", conferindo-se tratamento isonômico aos dois sexos. Todavia, a previsão da simples "reserva" de vagas não gerava uma obrigação partidária de preenchê-las.

${ }^{120}$ Nesse sentido, observa-se que, ainda que os partidos não indicassem uma única candidata mulher, restringindo-se a indicar os $70 \%$ de candidatos homens, seria possível preencher o equivalente a $100 \%$ de vagas com tais candidatos.

${ }^{121}$ Em relação à questão de gênero, além de alterar certas condições da política de discriminação positiva, a minirreforma inovou ao determinar que o mínimo de 5\% dos recursos recebidos pelos partidos oriundos do Fundo Partidário deverá ser aplicados na criação e manutenção de programas de promoção e difusão da participação política das mulheres.
} 
obrigatórias $^{122}$, sem, entretanto, ser adotada qualquer sanção por seu descumprimento $^{123}$. Nesse sentido, a única consequência para o partido que não apresenta o mínimo de $30 \%$ de candidatas em suas listas eleitorais é o impedimento de preencher tais vagas reservadas com homens, de modo que as candidaturas não preenchidas por mulheres são "perdidas" ${ }^{124}$. Esse fato adquire pouca importância dado ao número de candidatos que podem ser registrados. Conforme debatido anteriormente, a falta de sanções, seja de cunho financeiro ou afetas ao próprio direito de concorrer, não impede o avanço da participação feminina na vida política. Porém, limita o potencial efetivo da ação de discriminação positiva.

Desde que as cotas foram implementadas no Brasil, contabilizaram-se 5 eleições para Deputados Federais. Nesse período, a evolução do número de candidaturas femininas foi consideravelmente mais elevado do que o de candidatas efetivamente eleitas. Conforme informação disponível no site do TSE, nas eleições gerais de 1998, pela primeira vez, o número de candidatas mulheres à Câmara dos Deputados ultrapassou a marca dos $10 \%$, embora não tenha atingido metade do percentual mínimo (25\%) estabelecido pela Lei de Cotas. No total, na primeira eleição realizada com a aplicação de cotas, as mulheres representaram $10,41 \%$ das candidaturas aptas e conquistaram 5,65\% dos assentos disponíveis. Em 2014, o número de candidatas concorrendo ao cargo de Deputada Federal permaneceu aquém do percentual mínimo estabelecido legalmente (30\%). As mulheres representaram 29,28\% das

\footnotetext{
${ }^{122}$ A nova redação alterou o art. $10, \S 3^{\circ}$ para: "Do número de vagas resultantes das regras previstas neste artigo, cada partido ou coligação preencherá o mínimo de trinta por cento e o máximo de setenta por cento para candidaturas de cada sexo", de modo que a interpretação dada pelo TSE é a de obrigatoriedade.

${ }^{123}$ Ao PL 141/2009, do qual resultou a Lei $n^{\circ} 5.498 / 2009$, foram apresentadas mais de 100 propostas de emenda, dentre elas, a Emenda $n^{\circ} 24$ da Senadora Lúcia Vânia (PSDB/GO), que condicionava o registro de candidatos partidários à observância da cota de $30 \%$ e a Emenda $n^{\circ} 84$ da Senador Flexa Ribeiro (PSDB/PA) que determinava uma premiação de repartição do Fundo Partidário aos partidos que elegessem candidatas mulheres, ambas rejeitadas.

${ }^{124} \mathrm{Na}$ prática, com a redação atual da lei de cotas, a mesma aplica-se mais no sentido de limitar a $70 \%$ das candidaturas o número de candidatos homens do que de garantir o mínimo de $30 \%$ de candidatas mulheres.
} 
candidaturas aptas. Porém, a configuração da Câmara dos Deputados após as últimas eleições apresentou apenas um pequeno aumento de mulheres em número absoluto, de modo que, com 51 deputadas eleitas, o número de mulheres equivaleu a 9,94\% das vagas em disputa. ${ }^{125}$ A Tabela 1 permite observar a evolução do número de candidaturas aptas de mulheres ao cargo de Deputado Federal desde a implementação das cotas, constatando-se uma ampliação absoluta no número de mulheres candidatas de quase cinco vezes desde 1998.

Tabela 1

Evolução das candidaturas aptas ao cargo de Deputado Federal por gênero

\begin{tabular}{cccccc}
\hline Ano & Mulheres & \% & Homens & \% & Total \\
\hline $\mathbf{1 9 9 8}$ & 356 & $10,41 \%$ & 3.061 & $89,59 \%$ & 3.417 \\
$\mathbf{2 0 0 2}$ & 490 & $11,40 \%$ & 3.808 & $88,60 \%$ & 4.298 \\
$\mathbf{2 0 0 6}$ & 628 & $12,67 \%$ & 4.328 & $87,33 \%$ & 4.956 \\
$\mathbf{2 0 1 0}$ & 935 & $19,07 \%$ & 3.969 & $80,93 \%$ & 4.904 \\
$\mathbf{2 0 1 4}$ & 1.724 & $\mathbf{2 9 , 2 8 \%}$ & 4.163 & $70,72 \%$ & 5.887 \\
\hline Fonte: TSE (2015) & & & & &
\end{tabular}

Quando se verifica o grupo de candidaturas inaptas, curiosamente, constata-se que esse foi o primeiro estrato em que as cotas de gênero previstas para as eleições proporcionais foram atingidas. Segundo dados do TSE, e conforme ilustrado na Tabela 2, em 2014, por exemplo, dos 7.140 candidatos ao cargo de Deputado Federal, 1.253 foram considerados inaptos, seja por indeferimento ou por renúncia em determinado momento do processo eleitoral. As 548 candidatas desse grupo corresponderam a $43,74 \%$ do total de inaptos e a $24,11 \%$ de todas as mulheres que se candidataram. Em comparação, embora o número total de candidatos homens seja consideravelmente mais elevado que o de mulheres, aqueles considerados inaptos, corresponderam tão somente a $14,48 \%$ do total de candidaturas masculinas ${ }^{126}$.

\footnotetext{
${ }^{125}$ Dados do TSE. Acesso em 04 de junho de 2015.

${ }^{126}$ Dados do TSE. Acesso em 06 de junho de 2015.
} 
Tabela 2

Candidaturas inaptas ao cargo de Deputado Federal por gênero - Eleições de 2014

\begin{tabular}{|c|c|c|c|c|}
\hline & $\begin{array}{c}\text { Candidaturas } \\
\text { Totais }\end{array}$ & $\begin{array}{c}\text { Candidaturas } \\
\text { Inaptas }\end{array}$ & $\begin{array}{c}\% \text { no grupo } \\
\text { de Inaptos }\end{array}$ & $\begin{array}{c}\text { \% de Inaptos no total } \\
\text { de candidaturas }\end{array}$ \\
\hline Mulheres & 2.272 & 548 & $43,74 \%$ & $24,11 \%$ \\
\hline Homens & 4.867 & 705 & $56,26 \%$ & $14,48 \%$ \\
\hline Total & 7.140 & 1.253 & $100 \%$ & $17,54 \%$ \\
\hline
\end{tabular}

Os recursos financeiros não influenciam apenas o resultado eleitoral, mas também o processo de definição das candidaturas. A disponibilidade de capital parece constituir um fator relacionado à elevada participação de mulheres no conjunto de candidaturas inaptas. Segundo análise feita com dados das eleições gerais de $2010^{127}$, entre as candidaturas femininas consideradas inaptas, $84,4 \%$ não dispunham de recursos financeiros e os 15,6\% restantes, dispuseram em média de aproximadamente 10 mil reais. Por outro lado, a proporção de homens inabilitados que receberam recursos representa mais do que dobro das mulheres em semelhante situação $(38,37 \%)$, e, além disso, cada homem dentro desse grupo, recebeu em média 25 mil reais. Como a realização de campanhas e a disponibilidade de recursos estão diretamente associados, pode-se inferir desses dados que um grupo de mulheres aceita participar de chapas partidárias para cumprimento da legislação de cotas, sem pretensões efetivas sobre a disputa eleitoral.

No nível de financiamento eleitoral, é fundamental compreender a posição partidária com relação ao gênero, pois o apoio do partido político pode alavancar ou oprimir candidaturas, sendo comprovada a elevada correlação entre sucesso eleitoral e financiamento de campanha. Por meio de análise das prestações de contas das eleições gerais de 2014 acessíveis no site do TSE ${ }^{128}$, e tomando por base os 1081 candidatos aptos ao cargo de Deputado Federal pelo

\footnotetext{
${ }^{127}$ JUNCKES, Ivan Jairo (et al). Posicionamento das Mulheres na Rede de Financiamento Eleitoral e seu Desempenho nas Eleições de 2010 no Brasil: a dinâmica estrutural da exclusão e marginalização feminina no poder político. In: Revista Latino-americana de Geografia e Gênero. Ponta Grossa, v. 6, n. 1, p.25-47.

${ }^{128} \mathrm{O}$ TSE constitui a fonte oficial de declaração de bens, rendimentos e gastos de campanha.
} 
estado do Rio de Janeiro, constatou-se que, embora as deputadas eleitas tenham sido tão financiadas ${ }^{129}$ quanto seus pares homens, o investimento médio partidário na totalidade de suas candidatas não alcançou a monta de metade do investimento médio realizado nos candidatos homens ${ }^{130}$. No mesmo sentido, levantamento realizado pelo jornal Folha de São Paulo, a partir dos R\$102,4 milhões distribuídos em 2010 pelos diretórios nacionais dos 14 maiores partidos do país, constatou-se que as mulheres receberam apenas $8 \%$ dos recursos, embora representassem 19,7\% das candidaturas, sendo que alguns partidos não distribuíram nenhum recurso às mulheres ${ }^{131}$.

Embora o aumento de candidaturas possa ser utilizado para mensurar a efetividade das cotas, o objetivo principal destas permanece sendo o acesso efetivo aos cargos de representação, já que as mulheres, assim como os homens, quando se candidatam, ao menos em tese, pretendem se eleger e não apenas competir. Por ser mais fácil para os selecionadores partidários incluir mulheres como candidatas do que tentar promover de fato suas candidaturas, alguns partidos podem recrutar mulheres sem capital político, somente para cumprir o que a legislação sobre cotas estabelece. Assim, quando a análise de resultados da aplicação das medidas de discriminação positiva se desloca para o universo dos eleitos, o cenário tende a ser menos animador do que o examinado no aumento das candidaturas de mulheres. Como se pode observar,

\footnotetext{
${ }^{129}$ Para os fins do presente estudo, considerou-se apenas o financiamento partidário, aqui entendido como os recursos advindos de doações de outros candidatos, partidos políticos e comitês financeiros e os repasses de recursos provenientes do Fundo Partidário.

${ }^{130} \mathrm{O}$ investimento médio partidário em candidatas mulheres correspondeu a $\mathrm{R} \$ 33.798,99$, enquanto em candidato, a $\mathrm{R} \$ 76.292,73$. Considerando-se os investimentos totais recebidos pelos candidatos, incluindo os privados e os recursos próprios, o investimento médio por candidato passa a ser de $\mathrm{R} \$ 48.503,84$ e $\mathrm{R} \$ 121.334,07$ para mulheres e homens respectivamente. Ressalta-se ainda que das 328 candidaturas femininas aptas, 46 não apresentaram prestação de contas e 71 declararam não terem recebido recursos.

${ }^{131}$ PRB e PPS, por exemplo, não distribuíram nenhum recurso às mulheres em 2010. Mesmo no PT, partido que em geral elege mulheres, as 71 candidatas a deputada federal - 20,9\% do total de candidaturas- receberam apenas 7,6\% dos recursos do diretório nacional. No PSDB, as mulheres receberam apenas $1,7 \%$ do recurso embora a proporção de candidaturas femininas fosse de $20,4 \%$. (Fonte: http://www1.folha.uol.com.br/fsp/poder/48104-mulheres-recebem-apenas-8-dos-repasses-dospartidos.shtml)
} 
a Tabela 3 ilustra que a evolução do número de candidatas eleitas permaneceu muito aquém da ampliação do número de candidaturas femininas, demonstrando a ausência de impacto das cotas sobre a eleição para a Câmara dos Deputados.

Tabela 3

Evolução do número de eleitos para o cargo de Deputado Federal por gênero

\begin{tabular}{cccccc}
\hline Ano & Mulheres & \% & Homens & \% & Total \\
\hline $\mathbf{1 9 9 8}$ & 29 & $5,65 \%$ & 484 & $94,35 \%$ & 513 \\
$\mathbf{2 0 0 2}$ & 42 & $8,19 \%$ & 471 & $91,81 \%$ & 513 \\
$\mathbf{2 0 0 6}$ & 45 & $8,77 \%$ & 468 & $91,23 \%$ & 513 \\
$\mathbf{2 0 1 0}$ & 45 & $8,77 \%$ & 468 & $91,23 \%$ & 513 \\
$\mathbf{2 0 1 4}$ & 51 & $9,94 \%$ & 462 & $90,06 \%$ & 513 \\
\hline Fonte: TSE (2015) & & & & &
\end{tabular}

Conforme apresentado ao longo do presente trabalho, diversos fatores de ordem estrutural, sistêmica e contextuais, como o sistema político adotado por um país, a ordenação de candidatos no interior de uma lista partidária e a fiscalização efetiva da aplicação das cotas, com a consequente aplicação de sanções, influenciam e estão, comprovadamente, associados às chances de as mulheres se elegerem. Entretanto, não há consenso sobre o peso desses fatores na responsabilidade pelo baixo resultado decorrente da aplicação da política de discriminação positiva no Brasil. Alguns aspectos são comumente apontados como relevantes para a manutenção do reduzido percentual de mulheres no Congresso Nacional, tais como a ausência de sanções legais aos partidos pelo descumprimento das cotas, o sistema de lista eleitoral adotado no país e o modo como é realizado o financiamento das campanhas eleitorais ${ }^{132}$. Estes e outros elementos estão presentes no debate que se desenvolve há algum tempo sobre uma possível Reforma Política no Brasil, conforme será demonstrado na seção seguinte.

\footnotetext{
132 ARAÚJO, Clara. Cotas e financiamento de campanha. In: Cadernos Adenauer XIV, no 3. São Paulo: Fundação Konrad Adenauer, 2013. P. 11-30
} 


\subsection{Reforma Política}

Reforma Política pode ser entendida, em sentido amplo, como uma reorganização generalizada do sistema político de uma nação que modifica suas instituições políticas, ou em uma concepção mais restrita, como a alteração significativa de regras para competições eleitorais periódicas, de forma a afetar o comportamento político e os padrões de interação política ${ }^{133}$. No Brasil, o tema de Reforma Política manteve-se em pauta desde os fins dos trabalhos da Assembleia Nacional Constituinte, o que exemplifica-se pela estipulação do plebiscito para definição da forma (República ou Monarquia) e sistema (Parlamentarismo ou Presidencialismo) de governo que deveriam vigorar no país. No período pós-redemocratização, a Reforma Política passou a ser defendida com base em dois argumentos distintos. O primeiro funda-se na crença de que o sistema político brasileiro padece de uma instabilidade crônica advinda da combinação entre presidencialismo e multipartidarismo, de modo que uma reforma deveria centrar-se em temas de maior magnitude, como a alteração da forma de governo, a alteração do sistema eleitoral e a estipulação de cláusulas de barreira. O segundo centra-se na ideia de aperfeiçoamento das instituições já existentes no sistema político-eleitoral brasileiro, de modo que a representação proporcional deveria ser aprimorada por meio da elaboração de regras sobre fidelidade partidária, da proibição de coligações e da estipulação de critérios mais específicos de proporcionalidade, como sistemas de ordenamento de listas partidárias ${ }^{134}$.

A partir da década de 1990, alguns temas relevantes foram objeto de minirreformas políticas pontuais, como a redução, por ocasião da Revisão Constitucional de 1993, do mandato presidencial de 5 para 4 anos, a exclusão dos votos brancos do cálculo do quociente eleitoral, a instituição da reeleição para os cargos executivos e a aprovação, em 2006, do fim da verticalização

\footnotetext{
${ }^{133}$ ANASTASIA, Fátima. Reforma Política no Brasil. Belo Horizonte: UFMG. 2008. P.11.

${ }^{134}$ MELO, Carlos Ranulfo. Reforma Política em Perspectiva Comparada na América do Sul. In: ANASTASIA, Fátima. Reforma Política no Brasil. Belo Horizonte: UFMG. 2008. p.55
} 
obrigatória das coligações partidárias. Durante o governo Lula, a Câmara dos Deputados institui a Comissão Especial para a Reforma Política, que realizou um vasto levantamento de todas as propostas existentes no Congresso e encaminhou, em dezembro de 2003, à Comissão de Constituição e Justiça, o Projeto de Lei $\mathrm{n}^{\circ} 2.679$, que não chegou a ser apreciado ou votado. O projeto propunha: (i) a adoção do sistema de listas fechadas; (ii) a proibição de coligações para as eleições proporcionais; (iii) a criação de regras para fidelidade partidária; (iv) a instituição de uma cláusula de barreira; e (v) o financiamento público exclusivo das campanhas eleitorais ${ }^{135}$.

Observa-se que, com o decorrer do tempo, a discussão sobre reforma política no Brasil manteve-se em pauta no Poder Legislativo. Porém, talvez por ausência de pressões sociais ou pela inexistência de uma coalização capaz de contornar obstáculos institucionais, a agenda reformista realizou-se de forma muito precária. Em face das manifestações de junho de 2013, o tema voltou a receber grande atenção midiática e, com o aumento das pressões sociais, a votação de uma Reforma Política no Congresso Nacional foi concretizada. O Senado Federal possui, desde 2011, uma comissão mista que vem debatendo o assunto, e a Câmara dos Deputados começou a votar a matéria em maio de 2015. Os pontos principais elencados para votação são: (i) Sistema eleitoral (sistema de voto em lista; distrital misto; "distritão"; ou "distritão" misto); (ii) Financiamento de campanhas público; (iii) fim da reeleição para cargos executivos; (iv) duração dos mandatos de cargos eletivos; (v) fim das coligações; (vi) cláusula de barreira; (vii) voto facultativo; e (viii) cotas para mulheres.

\footnotetext{
${ }^{135}$ SOARES, Gláucio e RENNÓ, Lúcio. Reforma política - lições da história recente. Rio de Janeiro: FGV. 2006 apud MELO, Carlos Ranulfo. Reforma Política em Perspectiva Comparada na América do Sul. In: ANASTASIA, Fátima. Reforma Política no Brasil. Belo Horizonte: UFMG. 2008. p.55
} 


\subsubsection{Reforma Política e Igualdade de Gênero}

Reformas Políticas costumam ser fenômenos complexos, abordando uma amplitude de temas pelos quais a questão de igualdade de gênero pode perpassar, mas não de forma independente de outros temas caros à ideia de democracia. Para que a representação parlamentar feminina possa crescer de maneira mais expressiva, será preciso avançar na reforma e mudar os termos da Lei de Cotas, alterando disposições originais que tolhem os efeitos da ação de discriminação positiva, ou complementando suas lacunas, quando necessário. A saber, disposições que tornam a Lei de Cotas pouco eficaz são: (i) a ampliação do universo de candidaturas registrável por partido para $150 \%$ do número de vagas; (ii) a ausência de sanções por seu descumprimento; (iii) o percentual relativamente baixo da cota mínima, que passa a ser visto como teto e não como piso de candidaturas do gênero sub-representado; e (iv) a ausência de mecanismos que garantam às mulheres acesso a recursos financeiros e espaço na mídia ${ }^{136}$.

Na Reforma Política atualmente em debate no Congresso Nacional, alguns itens da agenda de votação abordam diretamente a proporcionalidade da representatividade parlamentar e as cotas eleitorais, por vezes, sugerindo mudanças nos pontos supra elencados. Outros itens, como propostas de alteração do Sistema Eleitoral e de instituição de cláusulas de barreira, por exemplo, embora não sejam originalmente voltados para políticas de igualdade de gênero, podem ter consequências que sejam mais ou menos favoráveis para o aumento da bancada feminina no Legislativo Nacional, pelos motivos expostos ao longo do presente trabalho.

No âmbito do tipo de cota adotado, tanto na Câmara dos Deputados quanto no Senado, foi proposta a alteração da Cota Legal Sobre o Processo Eleitoral para a Cota Legal de Reserva de Assentos Parlamentares. Na Câmara

\footnotetext{
${ }^{136}$ ALVES, José Eustáquio (et al) Participação das mulheres nas eleições de 2004: avaliação da política de cotas no Brasil. In: Congreso de La Asociación Latinoamericana de Sociología, 25., 2005, Porto Alegre.
} 
Alta, o texto original do Projeto de Lei $n^{\circ} 295 / 2011^{137}$, que já está pronto para deliberação do Plenário, estabelecia a destinação para preenchimento por mulheres de 50\% das vagas nas eleições proporcionais. O PLS sofreu emenda ao passar pela Comissão de Constituição, Justiça e Cidadania, tendo sua redação alterada para contemplar que a representação dos Estados, do Distrito Federal e dos Territórios Federais terá "ao menos" 50\% das vagas reservadas para preenchimento por mulheres. Em proposta alternativa, a Proposta de Emenda à Constituição no $23 / 2015^{138}$ estabelece a reserva de assentos a ser adotada progressivamente, iniciando-se em 30\%, com aumento de 5\% a cada pleito eleitoral, até que fosse atingida a paridade. A PEC em questão também sofreu emenda ao passar pela Comissão de Constituição, Justiça e Cidadania, mas, ao contrário do PLS 295/11, a nova redação adotada restringia a reserva de vagas aos $30 \%$ iniciais.

Um segundo grupo de propostas trabalha em cima da manutenção das Cotas Legais Sobre o Processo Eleitoral, alterando alguns elementos chave de sua constituição. O Projeto de Lei $n^{\circ} 27 / 2015^{139}$, também do Senado, propunha a alteração da redação da Lei de Cotas para garantir o preenchimento por parte dos partidos de $50 \%$ das vagas nas eleições proporcionais para candidatos de cada sexo, além de estabelecer reserva de tempo de propaganda eleitoral no rádio e na televisão para candidaturas de mulheres. O PLS previa também a rejeição da lista de candidaturas no caso do descumprimento da cota mínima, mas foi retirado pela autora e teve sua tramitação interrompida. Na Câmara dos Deputados tramita proposta que determina que, nos pleitos proporcionais, se o partido conquistar no mínimo três vagas, e os dois candidatos mais votados forem de um gênero, a terceira vaga será ocupada pelo candidato/a do outro

\footnotetext{
137 http://www.senado.leg.br/atividade/materia/detalhes.asp?p_cod_mate=100420. Acesso em: 06 de junho de 2015.

${ }^{138} \mathrm{http} / / / \mathrm{www}$. senado.gov.br/atividade/materia/detalhes.asp?p_cod_mate=120076. Acesso em: 06 de junho de 2015.

${ }_{139}$ http://www.senado.gov.br/atividade/materia/detalhes.asp?p_cod_mate=119685. Acesso em: 06 de junho de 2015.
} 
gênero mais votado, desde que este/a atinja o mínimo de $10 \%$ do quociente eleitoral $^{140}$

Por fim, também atinge diretamente o tema de igualdade de representação dos gêneros, o grupo de propostas sobre financiamento eleitoral. Conforme demonstrado anteriormente, as cotas como aplicadas atualmente não obtiveram a necessária correspondência do apoio partidário no que se refere a alocação de recursos financeiros nas candidatas mulheres. Os projetos sobre financiamento eleitoral, em uma escala maior não-restrita à questão de gênero, debatem se as campanhas políticas poderão ser financiadas somente por recursos públicos, ou se serão mantidas as doações privadas. Outras proposições, como o Projeto de Lei $\mathrm{n}^{\mathrm{o}} 112 / 2015^{141}$ do Senado, buscam alterar as normas de destinação do Fundo Partidário, destinando parte de seus recursos às campanhas eleitorais de candidatas. O texto proposto pelo referido PLS estipula que no mínimo $30 \%$ do total recebido do Fundo Partidário seja destinado a criação e manutenção de programas de promoção e difusão da participação política das mulheres, bem como em suas campanhas eleitorais ${ }^{142}$.

Qualquer sistema político, após razoável tempo de funcionamento, ainda que apresente problemas, tem a seu favor o fato da inércia. Os atores políticos já estão familiarizados com as estruturas e com as estratégias de ação que obtém os melhores resultados. A alteração, por mais bem-intencionada que seja, e ainda que temporária, desse quadro é sempre feita com cautela, posto que os realizadores da Reforma Política almejam manter-se no poder e o receio de não consegui-lo, muitas vezes, torna-se razão suficiente para bloquear

\footnotetext{
${ }^{140} \mathrm{http}$ ///oglobo.globo.com/brasil/deputadas-relatam-resistencia-de-bancadas-conservadoras-cota-paramulheres-16355732. Acesso em: 06 de junho de 2015.

${ }^{141} \mathrm{http} / / / \mathrm{www}$. senado.leg.br/atividade/materia/detalhes.asp?p_cod_mate=120079. Acesso em: $06 \mathrm{de}$ junho de 2015.

${ }^{142}$ Tal medida, por óbvio, seria mais eficiente caso o financiamento de campanhas fosse estritamente público, uma vez que implicaria na destinação de 30\% dos recursos totais disponíveis aos partidos, sem margem de manutenção de desigualdades por meio de financiamentos privados.
} 
processos reformistas $^{143}$. Nesses termos, considerando que a atual proposta de Reforma Política ainda está em debate no Congresso Nacional, não há como se prever os possíveis resultados das deliberações parlamentares.

${ }^{143}$ MOREIRA, Marcelo S. A poliarquia brasileira e a reforma política: análise de uma contribuição de Wanderley Guilherme dos Santos à Teoria Política. In: DADOS - Revista de Ciências Sociais, Rio de Janeiro, vol. 57, n², 2014. Pp. 293 a 323. 


\section{CONCLUSÃO}

O trabalho teve origem na proposta de analisar as chances de acesso das mulheres à representação política, particularmente à representação legislativa, e as formas como os partidos políticos se comprometem com a igualdade de gênero em sua atuação como mediadores das rotas de ingresso aos cargos eletivos de representação política. Buscou-se compreender os motivos que fazem com o que o Brasil apresente um dos mais baixos índices no mundo de representatividade feminina em seu Congresso Nacional, a partir da análise da aplicação da Lei de Cotas aos pleitos eleitorais. Para tanto, fez-se necessário considerar a dimensão histórica da exclusão das mulheres da condição de cidadãs e no desenvolvimento das democracias modernas, assim como as dimensões institucionais do sistema político nacional e as características do sistema partidário.

Comprovou-se que uma democracia representativa contemporânea pressupõe um conjunto de instituições que disciplinam a participação popular no processo político, o que, com a adoção de um sistema partidário, significa que o acesso a cargos representativos passa a ser intermediado por partidos políticos. Nesse diapasão, a participação de grupos minoritários, na esfera política institucionalizada, depende de uma ação positiva dos partidos políticos em seu recrutamento eleitoral. O sistema partidário articula-se com o sistema político, que possui variáveis que o tornam menos ou mais "amigáveis às mulheres". O Sistema Proporcional permite que os partidos apresentem listas de candidatos que contemplem múltiplos nomes, realizando-se a inclusão de candidatos de diversas configurações sociais, garantindo-se que as minorias alcancem representatividade nos mais diversos níveis de poder. No interior da família dos Sistemas Proporcionais, verificou-se que o desafio para mulheres depende do tipo de lista de ordenamento de candidatos adotada pelo país. No Brasil, o sistema de lista aberta implica que a inclusão de mulheres no pleito 
eleitoral é mais facilmente garantida do que a obtenção de prioridade das mesmas em relação aos recursos e investimentos partidários.

A relevância dos partidos políticos foi melhor explicitada ao analisar-se o funcionamento do recrutamento político e como as variáveis organizacionais e ideológicas afetam o modo como os partidos políticos lidam com as demandas por igualdade de gênero na política. Destacou-se que um alto grau de institucionalização é desejável, posto que permite a previsibilidade e o planejamento eleitoral de candidatos. Identificou-se também que partidos de viés ideológico identificado como de esquerda, tendem a adotar medidas mais incisivas para promoção de candidaturas femininas.

Diferentes medidas podem ser adotas por partidos ou por Estados para promover a igualdade de gênero e garantir uma presença mais elevada de mulheres nos órgãos representativos. Destacaram-se as políticas de discriminação positiva, sobretudo aquelas impostas pelo Estado por via constitucional ou legislativa sobre os processos eleitorais. Comprovou-se que a imposição de cotas legais não é suficiente para assegurar a paridade de gêneros no âmbito parlamentar, quando a mesma não é acompanhada por sanções efetivas quanto a não conformidade e por critérios de ordenamento interno de listas partidárias. A partir da estipulação de uma política de cotas bem elaborada, o partido político passa a ser responsável pela decisão de cumprimento ou não das disposições legais, o que pode corresponder a um compromisso formal de seguir a lei para não arcar com punições, ou um compromisso material, em que o partido oferece a suas candidatas condições de elegibilidade em igualdade aos homens.

No Brasil, a Lei de Cotas para surtir efeito significativo, necessitaria de cooperação considerável dos partidos políticos, posto que possui certas disposições que a tornam por si só pouco eficaz, como a ampliação do universo de candidaturas registáveis por partido para $150 \%$ do número de vagas, a ausência de sanções por seu descumprimento, o percentual relativamente baixo 
da cota mínima e a ausência de mecanismos que garantam que os partidos concedam às mulheres acesso a recursos financeiros e espaço na mídia. A Reforma Política, atualmente em debate no Congresso Nacional, tangencia alguns desses pontos, mas, considerando o histórico nacional de reformas, não há indícios de que os atores políticos estejam dispostos a aprovar mudanças na legislação que impliquem, ao menos de imediato, na alteração da engenharia política eleitoral e em modificações na estrutura de distribuição de poder.

Com efeito, as políticas de cotas contam e podem contribuir para a ampliação da presença de mulheres no âmbito da apresentação de candidaturas. Entretanto, quando se trata do momento da eleição, no caso brasileiro, devido à característica do sistema de listas abertas e à individualização da competição eleitoral, com as disposições da Lei de Cotas vigente, o efeito das cotas fica condicionado à lógica do sistema eleitoral, bem como aos arranjos políticos oriundos da mesma. Da forma como as cotas têm sido incorporadas no ordenamento brasileiro, qualquer chance de concretização de sua efetividade depende consideravelmente do compromisso político-partidário com a igualdade de gênero. 


\section{BIBLIOGRAFIA}

ÁLVARES, Maria Luzia Miranda. Mulheres Brasileiras em Tempo de Competição Eleitoral: Seleção de Candidaturas e Degraus de Acesso aos Cargos Parlamentares. DADOS - Revista de Ciências Sociais, Rio de Janeiro, Vol. 51, nº4, 2008, pp. 895 a 939.

ALVES, Branca. Moreira. Ideologia e feminismo: a luta da mulher pelo voto no Brasil. Petrópolis: Vozes, 1980.

ALVES, José Eustáquio (et al) Participação das mulheres nas eleições de 2004: avaliação da política de cotas no Brasil. In: Congreso de La Asociación Latinoamericana de Sociología, 25., 2005, Porto Alegre.

ANASTASIA, Fátima (et al). Reforma Política no Brasil. Belo Horizonte: UFMG. 2008.

ARAÚJO, Clara. As cotas por sexo para a competição legislativa: o caso brasileiro em comparação com experiências internacionais. In Revista Dados, v. 44, n. 1. Rio de Janeiro: 2001

. Partidos políticos e gênero: mediações nas rotas de ingresso das mulheres na representação política. Revista de Sociologia e Política, núm. 24, jun; 2005, pp. 193-215. Universidade Federal do Paraná, Curitiba, Brasil.

. Por Que Uma Reforma Eleitoral Mais Ampla É Importante Para As Mulheres? Revista Gênero na Amazônia, no 4, jul./dez., 2013. pp. 37-49.

Cotas e financiamento de campanha. In: Cadernos Adenauer XIV, no 3. São Paulo: Fundação Konrad Adenauer, 2013. P. 11-30 
ARAÚJO, Clara, e ALVES, José Eustáquio Diniz. Impactos de Indicadores Sociais e do Sistema Eleitoral sobre as Chances das Mulheres nas Eleições e suas Interações com as Cotas. Revista de Ciências Sociais, Rio de Janeiro, Vol. 50, no 3, 2007. pp. 535 a 577.

ARAÚJO, Clara, e BORGES, Doriam. Trajetórias Políticas E Chances Eleitorais: Analisando O “Gênero" Das Candidaturas Em 2010. Revista de Sociologia e Política 21, nº 46, 2013. pp. 69-91.

AVELAR, Lúcia. O Segundo Eleitorado: Tendências do Voto Feminino no Brasil. Campinas: Editora da Unicamp, 1989.

BACHARACH, Peter e BARATZ, Morton S. Decisions and Non-Decisions: An Analytical Framework. American Political Science Review. Washington (DC), v. 57, n.3, p. 632-642, sept., 1963.

BOUDON, Raymond e FRANÇOIS, Bourricaud. Dicionário crítico de sociologia. São Paulo: Ática. 1973. p. 342

CABANILLAS, Beatriz Llanos. A modo de introducción: caminos recorridos por la paridad en el mundo. In: La apuesta por la paridad: democratizando el sistema político en América Latina. Los casos de Ecuador, Bolivia y Costa Rica. Peru: IDEA Internacional/ CIM Comissão Interamericana de Mulheres, 2013. p. 17-46.

COSTA, Luiz Domingos, BOLOGNESI, Bruno e CODATO, Adriano. Variáveis sobre o recrutamento político e a questão de gênero no Parlamento brasileiro. Working Papers/Textos para Discussão, núm. 7, mai, 2013. (acessível em: “http://observatory-elites.org/wp-content/uploads/2012/06/wpobservatory-n.7-2013.pdf') 
DAHLERUP, Drude. From a Small to a Large Minority: Women in Scandinavian Politics. In: Scandinavian Political Studies, 11, p. 275-298, 1998.

GARCIA-PELAYO, Manuel. El Estado de partidos. Madrid: Alianza, 1986.

GUADAGNINI, Marila. A "Partitocrazia" without Women: The Case of Italian Party System. In: LOVENDUSKI, Joni e NORRIS, Pippa. Women and Politics. Oxford: Oxford Univerisity. 1996.

HELGESEN, Vidar. Discurso proferido em 06 de Março de 2012, em Nova York, na Comissão das Nações Unidas para a condição feminina. Texto traduzido pela autora.

IDEA, IPU, Stockholm University. Atlas of Electoral Gender Quotas, 2013. (Acessível em: http://www.idea.int/publications/atlas-of-electoral-genderquotas/)

IDEA, IPU, Stockhom University. Global Database of Quotas for Women. (Acessível em: www.quotaproject.org)

IPU. Men and women in politics: democracy still in the making. A comparative study. Report and documents n. 28. Genéva: Inter-Parliamentary Union. 1997.

IPU and UN Women, "Women in Politics: 2015”.

JUNCKES, Ivan Jairo (et al). Posicionamento das Mulheres na Rede de Financiamento Eleitoral e seu Desempenho nas Eleições de 2010 no Brasil: a dinâmica estrutural da exclusão e marginalização feminina no poder político. In: Revista Latino-americana de Geografia e Gênero. Ponta Grossa, v. 6, n. 1, p. 25-47. 
LIPJHART, Arend. Modelos de democracia. Rio de Janeiro: Ed. Civilização Brasileira, 2003.

LOVENDUSKI, Joni. Sex, Gender and British Politics. In: NORRIS, Pippa, e LOVENDUSKI, Joni. Gender and Party Politics. Londres: Sage, 1993.

MELO, Carlos Ranulfo. Reforma Política em Perspectiva Comparada na América do Sul. In: ANASTASIA, Fátima (et al). Reforma Política no Brasil. Belo Horizonte: UFMG. 2008.

MIGUEL, Sônia Malheiros. A política de cotas por sexo: um estudo das primeiras experiências no Legislativo brasileiro. Brasília: CFEMEA, 2000.

MOREIRA, Marcelo S. A poliarquia brasileira e a reforma política: análise de uma contribuição de Wanderley Guilherme dos Santos à Teoria Política. In: DADOS - Revista de Ciências Sociais, Rio de Janeiro, vol. 57, nº2, 2014. Pp. 293 a 323.

NORRIS, Pippa, e LOVENDUSKI, Joni. Gender and Party Politics. Londres: Sage, 1993.

NORRIS, Pippa. Recrutamento Político. In: CROTTY, W. \& KATZ, R. S. (eds) Handbook of Party Politics. Londres: Sage, 2006. Tradução de BOLOGNESI, Bruno.

SILVA. José Afonso da. Curso de Direito Constitucional Positivo. São Paulo: Malheiros Editores, 2011.

SOARES, Gláucio e RENNÓ, Lúcio. Reforma política - lições da história recente. Rio de Janeiro: FGV. 2006 apud MELO, Carlos Ranulfo. Reforma Política em Perspectiva Comparada na América do Sul. In: ANASTASIA, Fátima (et al). Reforma Política no Brasil. Belo Horizonte: UFMG. 2008. 
SUPLICY, Marta. Discurso. Diário do Congresso Nacional, Brasília, 04 ago. 1995. Seção I, p. 15855-15856.

TABAK, Fanny. A necessidade de uma re-conceitualização. In: TABAK, Fanny. Mulheres Públicas: Participação Política e Poder. Rio de Janeiro: Letra Capital, 2002.

TAVARES, José Giusti. Sistemas eleitorais e federação no Brasil: as lições da Alemanha. Texto apresentado na Conferência Internacional "Reforma política no Brasil em perspectiva comparada" realizado em junho de 2002 no Rio de Janeiro.

TEBET, Ramez. Discurso. Diário do Senado Federal, Brasília, 22 out. 1996. p. 17295 . 
ANEXO I

Tabela A - Lista de Países, Tipo de Parlamento, Tipo de Cota Adotada, Sistema Eleitoral e Percentual de Mulheres

\begin{tabular}{|c|c|c|c|c|c|c|}
\hline País & $\begin{array}{c}\text { Tipo de } \\
\text { Parlamento }\end{array}$ & Tipo de Cota & Total de Assentos & $\begin{array}{l}\text { Assentos Ocupados } \\
\text { por Mulheres na } \\
\text { Câmara Baixa/Única }\end{array}$ & $\%$ de Mulheres & Sistema Eleitoral \\
\hline Afeganistão & Bicameral & Reserva de Assentos & 249 & 69 & $28 \%$ & Outros \\
\hline África do Sul & Bicameral & Não há cota legal & 400 & 163 & $41 \%$ & Proporcional \\
\hline Albânia & Unicameral & Sobre o Processo Eleitoral & 140 & 25 & $18 \%$ & Proporcional \\
\hline Alemanha & Bicameral & Não há cota legal & 630 & 229 & $36 \%$ & Misto \\
\hline Angola & Unicameral & Sobre o Processo Eleitoral & 220 & 75 & $34 \%$ & Proporcional \\
\hline Arábia Saudita & Unicameral & Reserva de Assentos & 151 & 30 & $20 \%$ & $\begin{array}{l}\text { Não há previsão de eleições } \\
\text { diretas }\end{array}$ \\
\hline Argélia & Bicameral & Reserva de Assentos & 462 & 146 & $32 \%$ & Proporcional \\
\hline Argentina & Bicameral & Sobre o Processo Eleitoral & 257 & 94 & $37 \%$ & Proporcional \\
\hline Armênia & Unicameral & Sobre o Processo Eleitoral & 131 & 14 & $11 \%$ & Misto \\
\hline Austrália & Bicameral & Não há cota legal & 150 & 39 & $26 \%$ & Majoritário \\
\hline Áustria & Bicameral & Não há cota legal & 183 & 61 & $33 \%$ & Proporcional \\
\hline Bangladesh & Unicameral & Reserva de Assentos & 348 & 69 & $20 \%$ & Majoritário \\
\hline Bélgica & Bicameral & Sobre o Processo Eleitoral & 150 & 59 & $39 \%$ & Proporcional \\
\hline Bolívia & Bicameral & Sobre o Processo Eleitoral & 130 & 69 & $53 \%$ & Misto \\
\hline Bósnia e Herzegovina & Bicameral & Sobre o Processo Eleitoral & 42 & 9 & $21 \%$ & Proporcional \\
\hline Botsuana & Unicameral & Não há cota legal & 63 & 6 & $10 \%$ & Majoritário \\
\hline Brasil & Bicameral & Sobre o Processo Eleitoral & 513 & 51 & $10 \%$ & Proporcional \\
\hline $\begin{array}{l}\text { Brazzaville (República } \\
\text { do Congo) }\end{array}$ & Bicameral & Sobre o Processo Eleitoral & 136 & 10 & $7 \%$ & Majoritário \\
\hline Burquina Faso & Bicameral & Sobre o Processo Eleitoral & 127 & 20 & $16 \%$ & Proporcional \\
\hline
\end{tabular}




\begin{tabular}{|c|c|c|c|c|c|c|}
\hline País & $\begin{array}{c}\text { Tipo de } \\
\text { Parlamento }\end{array}$ & Tipo de Cota & Total de Assentos & $\begin{array}{l}\text { Assentos Ocupados } \\
\text { por Mulheres na } \\
\text { Câmara Baixa/Única }\end{array}$ & $\%$ de Mulheres & Sistema Eleitoral \\
\hline Burundi & Bicameral & Reserva de Assentos & 105 & 34 & $32 \%$ & Proporcional \\
\hline Cabo Verde & Unicameral & Sobre o Processo Eleitoral & 72 & 15 & $21 \%$ & Proporcional \\
\hline Camarões & Unicameral & Não há cota legal & 180 & 56 & $31 \%$ & Majoritário \\
\hline Canadá & Bicameral & Não há cota legal & 308 & 76 & $25 \%$ & Majoritário \\
\hline Cazaquistão & Bicameral & Não há cota legal & 107 & 26 & $24 \%$ & Proporcional \\
\hline Chile & Bicameral & Não há cota legal & 120 & 19 & $16 \%$ & Proporcional \\
\hline China & Unicameral & Reserva de Assentos & 2987 & 699 & $23 \%$ & $\begin{array}{l}\text { Não há previsão de eleições } \\
\text { diretas }\end{array}$ \\
\hline Chipre & Unicameral & Não há cota legal & 56 & 6 & $11 \%$ & Proporcional \\
\hline Colômbia & Bicameral & Sobre o Processo Eleitoral & 165 & 33 & $20 \%$ & Proporcional \\
\hline $\begin{array}{l}\text { Congo, República } \\
\text { Democrática do }\end{array}$ & Bicameral & Sobre o Processo Eleitoral & 492 & 44 & $9 \%$ & Misto \\
\hline Coréia do Sul & Unicameral & Sobre o Processo Eleitoral & 300 & 47 & $16 \%$ & Misto \\
\hline Costa do Marfim & Unicameral & Não há cota legal & 255 & 28 & $11 \%$ & Majoritário \\
\hline Costa Rica & Unicameral & Sobre o Processo Eleitoral & 57 & 19 & $33 \%$ & Proporcional \\
\hline Croácia & Unicameral & Sobre o Processo Eleitoral & 151 & 36 & $24 \%$ & Proporcional \\
\hline Djibuti & Unicameral & Reserva de Assentos & 65 & 7 & $11 \%$ & Misto \\
\hline Dinamarca & Unicameral & Não há cota legal & 179 & 70 & $39 \%$ & Proporcional \\
\hline Egito & Bicameral & Sobre o Processo Eleitoral & 508 & 10 & $2 \%$ & Misto \\
\hline El Salvador & Unicameral & Sobre o Processo Eleitoral & 84 & 23 & $27 \%$ & Proporcional \\
\hline Equador & Unicameral & Sobre o Processo Eleitoral & 137 & 53 & $39 \%$ & Proporcional \\
\hline Eritreia & Unicameral & Reserva de Assentos & 105 & 22 & $21 \%$ & $\begin{array}{l}\text { Não há previsão de eleições } \\
\text { diretas }\end{array}$ \\
\hline Eslováquia & Unicameral & Não há cota legal & 150 & 28 & $19 \%$ & Proporcional \\
\hline
\end{tabular}




\begin{tabular}{|c|c|c|c|c|c|c|}
\hline País & $\begin{array}{c}\text { Tipo de } \\
\text { Parlamento }\end{array}$ & Tipo de Cota & Total de Assentos & $\begin{array}{l}\text { Assentos Ocupados } \\
\text { por Mulheres na } \\
\text { Câmara Baixa/Única }\end{array}$ & $\%$ de Mulheres & Sistema Eleitoral \\
\hline Eslovênia & Bicameral & Sobre o Processo Eleitoral & 90 & 32 & $36 \%$ & Proporcional \\
\hline Espanha & Bicameral & Sobre o Processo Eleitoral & 350 & 126 & $36 \%$ & Proporcional \\
\hline Etiópia & Bicameral & Não há cota legal & 547 & 152 & $28 \%$ & Majoritário \\
\hline Filipinas & Bicameral & Não há cota legal & 289 & 79 & $27 \%$ & Misto \\
\hline França & Bicameral & Sobre o Processo Eleitoral & 577 & 155 & $27 \%$ & Majoritário \\
\hline Gana & Unicameral & Não há cota legal & 275 & 30 & $11 \%$ & Majoritário \\
\hline Geórgia & Unicameral & $\begin{array}{l}\text { Financiamento público } \\
\text { adicional }\end{array}$ & 150 & 18 & $12 \%$ & Misto \\
\hline Grécia & Unicameral & Sobre o Processo Eleitoral & 300 & 69 & $23 \%$ & Proporcional \\
\hline Guatemala & Unicameral & Não há cota legal & 158 & 21 & $13 \%$ & Proporcional \\
\hline Guiana & Unicameral & Sobre o Processo Eleitoral & 67 & 21 & $31 \%$ & Proporcional \\
\hline Guiné & Unicameral & Sobre o Processo Eleitoral & 114 & 25 & $22 \%$ & Misto \\
\hline Guiné Equatorial & Bicameral & Não há cota legal & 100 & 22 & $22 \%$ & Proporcional \\
\hline Haiti & Bicameral & Reserva de Assentos & 95 & 4 & $4 \%$ & Majoritário \\
\hline Holanda & Bicameral & Não há cota legal & 150 & 58 & $39 \%$ & Proporcional \\
\hline Honduras & Unicameral & Sobre o Processo Eleitoral & 128 & 33 & $26 \%$ & Proporcional \\
\hline Hungria & Unicameral & Não há cota legal & 199 & 19 & $10 \%$ & Misto \\
\hline Ilhas Maurício & Unicameral & Não há cota legal & 69 & 8 & $12 \%$ & Majoritário \\
\hline Ilhas Salomão & Unicameral & Sobre o Processo Eleitoral & 50 & 1 & $2 \%$ & Majoritário \\
\hline Índia & Bicameral & Não há cota legal & 543 & 62 & $11 \%$ & Majoritário \\
\hline Indonésia & Unicameral & Sobre o Processo Eleitoral & 560 & 94 & $17 \%$ & Proporcional \\
\hline Iraque & Unicameral & Reserva de Assentos & 328 & 83 & $25 \%$ & Proporcional \\
\hline Irlanda & Bicameral & Sobre o Processo Eleitoral & 166 & 25 & $15 \%$ & Proporcional \\
\hline
\end{tabular}




\begin{tabular}{|c|c|c|c|c|c|c|}
\hline País & $\begin{array}{c}\text { Tipo de } \\
\text { Parlamento }\end{array}$ & Tipo de Cota & Total de Assentos & $\begin{array}{l}\text { Assentos Ocupados } \\
\text { por Mulheres na } \\
\text { Câmara Baixa/Única }\end{array}$ & $\%$ de Mulheres & Sistema Eleitoral \\
\hline Islândia & Unicameral & Não há cota legal & 63 & 25 & $40 \%$ & Proporcional \\
\hline Israel & Unicameral & Não há cota legal & 120 & 27 & $23 \%$ & Proporcional \\
\hline Itália & Bicameral & Não há cota legal & 630 & 179 & $28 \%$ & Proporcional \\
\hline Jordânia & Bicameral & Reserva de Assentos & 150 & 18 & $12 \%$ & Misto \\
\hline Lesoto & Bicameral & Sobre o Processo Eleitoral & 120 & 30 & $25 \%$ & Misto \\
\hline Líbano & Unicameral & Não há cota legal & 128 & 4 & $3 \%$ & Majoritário \\
\hline Libéria & Bicameral & Não há cota legal & 73 & 8 & $11 \%$ & Majoritário \\
\hline Líbia & Unicameral & Sobre o Processo Eleitoral & 200 & 30 & $15 \%$ & Misto \\
\hline Lituânia & Unicameral & Não há cota legal & 141 & 34 & $24 \%$ & Misto \\
\hline Luxemburgo & Unicameral & Não há cota legal & 60 & 14 & $23 \%$ & Proporcional \\
\hline Macedônia & Unicameral & Sobre o Processo Eleitoral & 123 & 40 & $33 \%$ & Proporcional \\
\hline Malaui & Unicameral & Não há cota legal & 192 & 32 & $17 \%$ & Majoritário \\
\hline Mali & Unicameral & Não há cota legal & 147 & 14 & $10 \%$ & Majoritário \\
\hline Malta & Unicameral & Não há cota legal & 70 & 10 & $14 \%$ & Proporcional \\
\hline Marrocos & Bicameral & Reserva de Assentos & 395 & 66 & $17 \%$ & Proporcional \\
\hline Mauritânia & Bicameral & Sobre o Processo Eleitoral & 147 & 37 & $25 \%$ & Majoritário \\
\hline México & Bicameral & Sobre o Processo Eleitoral & 500 & 184 & $37 \%$ & Misto \\
\hline Moçambique & Unicameral & Não há cota legal & 250 & 99 & $40 \%$ & Proporcional \\
\hline Moldávia & Unicameral & Não há cota legal & 101 & 20 & $20 \%$ & Proporcional \\
\hline Mongólia & Unicameral & Sobre o Processo Eleitoral & 74 & 10 & $14 \%$ & Misto \\
\hline Montenegro & Unicameral & Sobre o Processo Eleitoral & 81 & 12 & $15 \%$ & Proporcional \\
\hline Namíbia & Bicameral & Não há cota legal & 104 & 43 & $41 \%$ & Proporcional \\
\hline Nepal & Unicameral & Sobre o Processo Eleitoral & 597 & 176 & $29 \%$ & Misto \\
\hline
\end{tabular}




\begin{tabular}{|c|c|c|c|c|c|c|}
\hline País & $\begin{array}{c}\text { Tipo de } \\
\text { Parlamento }\end{array}$ & Tipo de Cota & Total de Assentos & $\begin{array}{l}\text { Assentos Ocupados } \\
\text { por Mulheres na } \\
\text { Câmara Baixa/Única }\end{array}$ & $\%$ de Mulheres & Sistema Eleitoral \\
\hline Nicarágua & Unicameral & Sobre o Processo Eleitoral & 92 & 37 & $40 \%$ & Proporcional \\
\hline Níger & Unicameral & Reserva de Assentos & 113 & 15 & $13 \%$ & Proporcional \\
\hline Noruega & Unicameral & Não há cota legal & 169 & 67 & $40 \%$ & Proporcional \\
\hline Palestina & Unicameral & Sobre o Processo Eleitoral & 132 & 17 & $13 \%$ & Proporcional \\
\hline Panamá & Unicameral & Sobre o Processo Eleitoral & 71 & 11 & $15 \%$ & Proporcional \\
\hline Paquistão & Bicameral & Reserva de Assentos & 342 & 67 & $20 \%$ & Misto \\
\hline Paraguai & Bicameral & Sobre o Processo Eleitoral & 80 & 14 & $18 \%$ & Proporcional \\
\hline Peru & Unicameral & Sobre o Processo Eleitoral & 130 & 28 & $22 \%$ & Proporcional \\
\hline Polônia & Bicameral & Sobre o Processo Eleitoral & 460 & 110 & $24 \%$ & Proporcional \\
\hline Portugal & Unicameral & Sobre o Processo Eleitoral & 230 & 61 & $27 \%$ & Proporcional \\
\hline Quênia & Bicameral & Reserva de Assentos & 350 & 65 & $19 \%$ & Majoritário \\
\hline Quirguistão & Unicameral & Sobre o Processo Eleitoral & 120 & 28 & $23 \%$ & Proporcional \\
\hline Reino Unido & Bicameral & Não há cota legal & 650 & 143 & $22 \%$ & Majoritário \\
\hline República Checa & Bicameral & Não há cota legal & 200 & 39 & $20 \%$ & Proporcional \\
\hline $\begin{array}{l}\text { República } \\
\text { Dominicana } \\
\end{array}$ & Bicameral & Sobre o Processo Eleitoral & 183 & 38 & $21 \%$ & Proporcional \\
\hline Romênia & Bicameral & Não há cota legal & 412 & 55 & $13 \%$ & Misto \\
\hline Ruanda & Bicameral & Sobre o Processo Eleitoral & 80 & 51 & $64 \%$ & Proporcional \\
\hline Samoa & Unicameral & Reserva de Assentos & 49 & 2 & $4 \%$ & Majoritário \\
\hline Senegal & Unicameral & Sobre o Processo Eleitoral & 150 & 64 & $43 \%$ & Misto \\
\hline Serra Leoa & Unicameral & Não há cota legal & 121 & 15 & $12 \%$ & Majoritário \\
\hline Sérvia & Unicameral & Sobre o Processo Eleitoral & 250 & 85 & $34 \%$ & Proporcional \\
\hline Somália & Unicameral & Reserva de Assentos & 275 & 38 & $14 \%$ & Em transição \\
\hline
\end{tabular}




\begin{tabular}{|c|c|c|c|c|c|c|}
\hline País & $\begin{array}{c}\text { Tipo de } \\
\text { Parlamento }\end{array}$ & Tipo de Cota & Total de Assentos & $\begin{array}{l}\text { Assentos Ocupados } \\
\text { por Mulheres na } \\
\text { Câmara Baixa/Única }\end{array}$ & $\%$ de Mulheres & Sistema Eleitoral \\
\hline Sri Lanka & Unicameral & Não há cota legal & 225 & 13 & $6 \%$ & Proporcional \\
\hline Suazilândia & Bicameral & Reserva de Assentos & 65 & 4 & $6 \%$ & Majoritário \\
\hline Sudão & Bicameral & Reserva de Assentos & 354 & 88 & $25 \%$ & Misto \\
\hline Sudão do Sul & Bicameral & Reserva de Assentos & 332 & 88 & $27 \%$ & Em transição \\
\hline Suécia & Unicameral & Não há cota legal & 349 & 152 & $44 \%$ & Proporcional \\
\hline Suíça & Bicameral & Não há cota legal & 200 & 57 & $29 \%$ & Proporcional \\
\hline Tailândia & Bicameral & Não há cota legal & 500 & 79 & $16 \%$ & Em transição \\
\hline Tanzânia & Unicameral & Reserva de Assentos & 350 & 126 & $36 \%$ & Majoritário \\
\hline Timor Leste & Unicameral & Sobre o Processo Eleitoral & 65 & 25 & $38 \%$ & Proporcional \\
\hline Togo & Unicameral & Sobre o Processo Eleitoral & 91 & 14 & $15 \%$ & Proporcional \\
\hline Trinidade e Tobago & Bicameral & Não há cota legal & 42 & 12 & $29 \%$ & Majoritário \\
\hline Tunísia & Unicameral & Sobre o Processo Eleitoral & 217 & 68 & $31 \%$ & Proporcional \\
\hline Turquia & Unicameral & Não há cota legal & 550 & 78 & $14 \%$ & Proporcional \\
\hline Uganda & Unicameral & Reserva de Assentos & 375 & 131 & $35 \%$ & Majoritário \\
\hline Uruguai & Bicameral & Sobre o Processo Eleitoral & 99 & 16 & $16 \%$ & Proporcional \\
\hline Uzbequistão & Bicameral & Sobre o Processo Eleitoral & 150 & 24 & $16 \%$ & Majoritário \\
\hline Vanuatu & Unicameral & Não há cota legal & 52 & 0 & $0 \%$ & Outros \\
\hline Venezuela & Unicameral & Não há cota legal & 165 & 28 & $17 \%$ & Misto \\
\hline Zimbábue & Bicameral & Reserva de Assentos & 270 & 85 & $31 \%$ & Majoritário \\
\hline
\end{tabular}


